\title{
Targeting Lysophosphatidic Acid in Cancer: The Issues in Moving from Bench to Bedside
}

Yan Xu

Department of Obstetrics and Gynecology, Indiana University School of Medicine, 950 W. Walnut Street R2-E380, Indianapolis, IN 46202, USA; xu2@iu.edu; Tel.: +1-317-274-3972

Received: 28 August 2019; Accepted: 8 October 2019; Published: 10 October 2019

check for updates

\begin{abstract}
Since the clear demonstration of lysophosphatidic acid (LPA)'s pathological roles in cancer in the mid-1990s, more than 1000 papers relating LPA to various types of cancer were published. Through these studies, LPA was established as a target for cancer. Although LPA-related inhibitors entered clinical trials for fibrosis, the concept of targeting LPA is yet to be moved to clinical cancer treatment. The major challenges that we are facing in moving LPA application from bench to bedside include the intrinsic and complicated metabolic, functional, and signaling properties of LPA, as well as technical issues, which are discussed in this review. Potential strategies and perspectives to improve the translational progress are suggested. Despite these challenges, we are optimistic that LPA blockage, particularly in combination with other agents, is on the horizon to be incorporated into clinical applications.
\end{abstract}

Keywords: Autotaxin (ATX); ovarian cancer (OC); cancer stem cell (CSC); electrospray ionization tandem mass spectrometry (ESI-MS/MS); G-protein coupled receptor (GPCR); lipid phosphate phosphatase enzymes (LPPs); lysophosphatidic acid (LPA); phospholipase $\mathrm{A}_{2}$ enzymes $\left(\mathrm{PLA}_{2} \mathrm{~s}\right)$; nuclear receptor peroxisome proliferator-activated receptor (PPAR); sphingosine-1 phosphate (S1P)

\section{Introduction}

Lysophosphatidic acids (LPAs) are simple lipids, but they are involved in virtually every aspect of tumor development, covering all 10 cancer hallmark activities [1-7]. They include, but are not limited to, stimulation of the proliferative signaling [8-10], evading growth suppressors and resisting cell death by regulating the apoptotic and other cell death/survival pathways [11,12], enabling replicative immortality by regulating telomerase [13], inducing angiogenesis and lymphangiogenesis via upregulation of proangiogenic factors, such as vascular endothelial growth factor A (VEGFA), vascular endothelial growth factor C (VAGFC), interleukin (IL)-1 $\beta$ [14-18] and IL-8 [19-21], and activating invasion and metastasis [22-26]. In addition, LPA affects genome instability (the autotaxin (ATX)-LPA axis is involved in reactive oxygen species (ROS)-induced genomic instability [27] and $\gamma$-irradiation-induced DNA damage repair [28], inflammation by regulating inflammatory factors, such as cyclooxygenase-2 (COX2), IL6, and Tumor necrosis factor-alpha (TNF $\alpha$ ) [29-31]) and energy metabolism (ATX-LPA signaling contributes to obesity-induced insulin resistance [32]; LPA triggers glycolytic shift and induces metabolic reprogramming in ovarian cancer via Rac-mediated activation of nicotinamide adenine dinucleotide phosphate oxidase (NADPH oxidase) and generation of reactive oxygen species (ROS), resulting in activation of hypoxia inducible factor 1-alpha (HIF1 $\alpha$ ) [33] and the immune system [1-7,34]). In particular, expression of ATX or each of the endothelial-derived G-protein-coupled receptor (EDG)-family LPA receptor (LPAR) $\left(\mathrm{LPAR}_{1-3}\right)$ in the mammary epithelium of transgenic mice was shown to be sufficient to induce breast cancer [26]. The current review does not cover these functions or signaling pathways in detail, but rather focuses on the issues pertinent to the 
translation of LPA targeting to clinic applications. The different aspects of LPA's functions in cancer were extensively reviewed over several decades [3-5,7,21,35-49].

The major challenges in moving LPA targeting to clinical practice include the complex metabolic network of LPA, the extremely broad and multifaceted pathological activities elicited by LPA, which are overlapping with its physiological activities, the complicated and potentially opposing cellular activities mediated by different LPA receptors in an individual cancer and individual patient-dependent manner, and the maze of intertwined G-protein coupling and downstream signaling pathway elicited by LPA through its own receptors, as well as many other types of cell receptors and signaling pathways. Moreover, technical issues for LPA detection and/or blockage, as well as study design issues are also major obstacles to overcome. This review focuses on these issues with perspectives to improve the LPA translational progress.

\section{LPA: From Bench to Bedside}

\subsection{A Brief History and Milestones of LPA Research}

\subsubsection{Before the Identification of LPA Receptors}

LPA was first described in the early 1960s [50,51]. It was later studied in almost all type of cells in organisms ranging from bacteria to plants to animals. In the 1960s, only eight papers were published related to LPA. This number increased to $\sim 40, \sim 100$, and $\sim 300$ in the 1970s, 1980s, and 1990s, respectively. At the turn of the century, the number of LPA-related studies increased exponentially to more than 4000 papers related to LPA published since the year 2000 (Figure 1). Among these LPA papers, 1300 papers are related to cancer/tumor, covering almost all types of solid and blood cancers/tumors (Figure 1). This list includes, but is not limited to, cancers of ovarian, lung, gastric, colorectal, breast, prostate, bladder, endometrial, renal, oral, pancreatic, cervical, and brain (including glioblastoma) origin, as well as leukemias, non-Hodgkin's lymphomas, fibrosarcoma, osteosarcoma, and melanoma $[3,4,21,48,52]$. Among these publications, $\sim 20 \%$ of the papers are related to ovarian cancer (OC) alone.

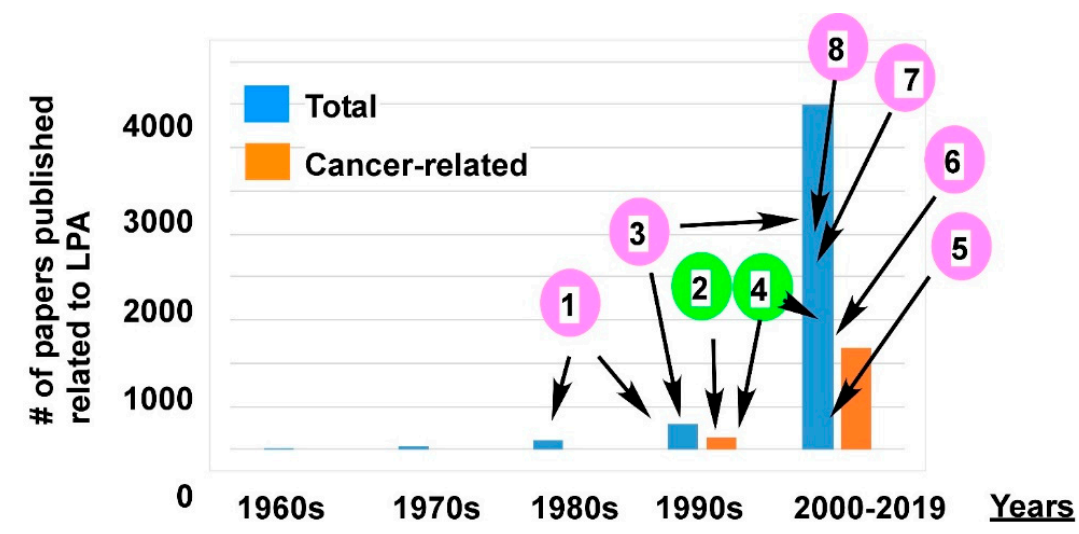

Figure 1. Lysophosphatidic acid (LPA)-related papers published in decades and the milestones in LPA research. The blue bars are the total number of LPA-related papers published in each decade. The orange bars are the numbers of LPA studies related to cancer. The pink circled numbers are milestones related to LPA research in general, and the green circled numbers are cancer-related milestones. (1) LPA's mitogen and growth factor like activity, as well as G-protein-mediated signaling mechanisms were discovered in the late 1980s and early 1990s [35,53-59]. (2) In 1995, the pathological significance of LPA in cancer was first reported [8-10]. (3) From 1996 to 2009, six LPA G-protein coupled receptors (GPCRs) were identified and cloned [60-71]. (4) From 1998 to the present, LPA as a putative cancer marker was reported [22,72-82]. (5) From 2000 to the present, new technologies, including the electrospray ionization tandem mass spectrometry (ESI-MS/MS) methods, were developed for LPA analyses [73,83-87]. In addition, LPA antibodies were developed and further improved. In 2008, Lpath 
Inc. successfully humanized an anti-LPA antibody. (6) In 2002, the major LPA-producing enzyme ATX was identified and cloned [88,89]. (7) From 2011 to 2017, ATX and LPA G-protein coupled receptors (GPCRs) were crystalized with their structures determined [90-94]. (8) From 2013 to the present, FDA-approved ATX and LPA receptor (LPAR) inhibitors entered clinical trials for fibrosis [95].

LPA was first isolated from brain extracts in 1961 [50]. Most studies on LPA at the early stage (from 1960s to 1970s) focused on the biochemical analyses of LPA, including enzymes involved in LPA metabolism and catabolism, as well as the tissue, cellular, and sub-cellular locations of LPA. Several of these studies are structure-activity studies, as LPA is a group of more than 20 molecules, varying in their fatty-acid chain location (sn-1 vs. sn-2 on the glycerol backbone), the numbers of carbons in the fatty-acid chain, the number and location of the double bonds in the fatty-acid chain, and also the chemical linkage between the fatty acid and the glycerol (ether linkage vs. ester linkage) [96-98].

The 1980s were the beginning decade for extensive functional and signaling studies of LPA. LPA-induced platelet aggregation and alterations in arachidonate metabolism were the earliest LPA functions revealed, which were further studied over the following decades [31,96,99-104]. The effects of LPA on ion channels were noticed as early as the 1980s [98] and regained more interest in recent years [98,105-110]. The intravenous injection of LPA induces hypertension in animals [97,111-113]. The mitogen (cell proliferation) activity of LPA was discovered in the late 1980s and early 1990s, before the molecular cloning of LPA receptors [35,53-56]. In addition, the potent effects of LPA on cell skeleton-related activities were reported in various cell types and/or organisms even before its receptors were identified/cloned in 1996. LPA induces contraction of rat isolated colon [114], reverts the $\beta$-adrenergic agonist-induced morphological response in C6 rat glioma cells [115], induces neuronal shape changes [57], and is a chemoattractant for Dictyostelium discoideum amoebae and human neutrophils [58,116]. Moreover, LPA inhibits gap-junctional communication and stimulates phosphorylation of connexin-43 in while blood cells. Focal adhesion kinase (FAK), paxillin, and p130 are important LPA-targeting genes/proteins [117-119].

In terms of signaling properties, calcium and cyclic adenosine monophosphate (cAMP) are the earliest revealed downstream signaling molecules for LPA [120]. Its regulation of protein phosphorylation was also discovered [117-119,121]. One of the milestone papers for LPA signaling published by Moolenaar's group in the late 1980s showed that LPA initiates at least three separate signaling cascades: activation of a pertussis toxin-insensitive G-protein mediating phosphoinositide hydrolysis with subsequent $\mathrm{Ca}^{2+}$ mobilization and stimulation of protein kinase $\mathrm{C}$; release of arachidonic acid in a guanosine triphosphate (GTP)-dependent manner, but independent of prior phosphoinositide hydrolysis; and activation of a pertussis toxin-sensitive $G_{i}$-protein mediating inhibition of adenylate cyclase [53]. Later, the same group of investigators identified Ras activation as an important downstream signaling pathway for LPA in fibroblasts $[59,119]$. Another important finding is that the cell skeleton effects of LPA are linked to the small GTP-binding protein Rho [122].

The implications of the potential roles of LPA in cancer stem from the findings for LPA's mitogenand growth factor-like activity in the late 1980s and early 1990s [35,53-59]. However, the majority of these studies were conducted in model cellular systems (mainly in fibroblasts). In 1995, in searching for the "ovarian growth factor" in human ascites from ovarian cancer patients, Xu et al. published three seminal papers linking pathologic LPA to cancer (breast and ovarian cancer cells, as well as leukemia cells) [8-10]. Since then, the research on the relevance of LPA in cancer and human health is booming (Figure 1).

\subsubsection{Post Identification of LPA Receptors}

Although G-protein-mediated LPA signaling pathways were identified as described above, molecular identification and cloning of LPA receptors in 1996 and the following years established the corner stones for rapid growth of LPA-related studies and targeting, as G-protein coupled receptors (GPCRs) represent targets for $\sim 40 \%$ of pharmacological drug antagonists [123]. 
The first LPA receptor was identified and cloned in 1996 [60], which was followed by cloning and identification of a total of six LPA receptors, namely $\mathrm{LPAR}_{1} / \mathrm{EDG}_{2}, \mathrm{LPAR}_{2} / \mathrm{EDG} 4$, $\mathrm{LPAR}_{3} / \mathrm{EDG} 7, \mathrm{LPAR}_{4} /$ purinergic G protein-coupled receptor P2Y9 (P2Y9/GPR23, LPAR $/$ GPR92, and $\mathrm{LPAR}_{6} / \mathrm{P} 2 \mathrm{Y}_{5}$ [61-71]. Several additional G-protein coupled receptors (GPCRs) were also shown to be putative LPA receptors, including GPR87 [124,125], GPR35 [126], and P2Y10 [127]. However, they are less studied and/or not confirmed as LPA receptors. Moreover, the nuclear receptor peroxisome proliferator-activated receptor gamma (PPAR $\gamma$ ) was identified as an intracellular LPA receptor [128-131]. PPAR $\gamma$ belongs to the nuclear receptor superfamily of PPARs (PPAR $\alpha$, PPAR $\beta / \delta$, and PPAR $\gamma$ ). PPARs play a role in inflammation and a variety of cancers which include prostate, breast, glioblastoma, neuroblastoma, pancreatic, hepatic, leukemia, and bladder and thyroid cancers [132], and they are mainly studied by using their natural and synthetic agonists or antagonists, including thiazolidinediones, different unsaturated fatty acids, and GW9662. The results are contradictory, with both pro- and anti-tumor roles of PPAR $\gamma$ reported [132]. LPA was identified as a new ligand for PPAR $\gamma$ in 2003 [60]. Until recently, LPA-PPAR $\gamma$ studies were mainly limited to the vascular and metabolic processes [130]. We recently showed that LPA upregulates an oncogene ZIP4 in epithelial ovarian cancer (EOC) cells, mainly via PPAR $\gamma$, and LPA's cancer stem cell (CSC)-promoting activities are mediated by $\operatorname{PPAR} \gamma$ [133].

Another important milestone in LPA research was the identification of the major LPA-producing enzyme, autotaxin (ATX). Although the enzymatic activity of the lysophospholipase D in the production of LPA was described earlier in rat plasma [134], the gene encoding this enzyme for this activity was not known until $2002[88,89]$.

The crystallization and structure determination for LPA GPCRs belonging to each of the two subclasses (EDG and purinergic receptors), as well as ATX [90-94], in recent years were pivotally important in design and development of anti-cancer reagents targeting them. In fact, Food and Drug Administration (FDA)-approved inhibitors against ATX and LPA monoclonal antibody entered into clinical trials for fibrosis [95] (Figure 1).

The functions/cellular effects of LPA (both physiological and pathological) are very broad, which were extensively reviewed [3,35,36,135-138]. The signaling pathways, mainly those mediated by LPA GPCR receptors, were also extensively studied and reviewed $[3,35,61,135,136,138,139]$. This review focuses on the challenges in moving bench LPA studies to clinical practice (bedside).

\subsection{Challenges and Obstacles of LPA Clinical Applications in Cancer}

\subsubsection{The Issues with LPA as a Marker for Cancer}

We initially reported LPA as a potential marker for ovarian cancer (OC) [72], which is supported by blinded [22] and numerous independent studies [73-81]. LPA was also shown to be a biomarker for other gynecological cancers [72], as well as for gastric cancer [82].

However, we are facing several challenges in moving LPA as a cancer marker to clinical application [7]. These issues are tightly related to the biochemical nature of LPAs, which are metabolites, having a quick turnover time due to their producing and degradation enzymes, as well as several other potential factors $[7,81,140,141]$. Many epidemiological factors, such as diet, smoking, and drinking may also have significant effects on LPA levels detected, which are not always included in various studies. Technical issues are another major concern. These issues include many different lipid extraction, storage, and detection methods used, which may generate LPA artefacts [7,141].

The analytic methods for LPA were greatly advanced from earlier (1960-1990s) thin-layer and high-performance liquid chromatography-based analyses $[8,142,143]$ to modern electrospray ionization tandem mass spectrometric (ESI-MS/MS) methods [73,83-87]. Another major technological advancement in LPA detection and targeting is the development of antibodies against LPA. LPA is not immunogenic, since all animal species produce LPA and LPA is very small (molecular weights ranging from 400 to $500 \mathrm{Da}$ ), lacking structural specificity to elicit a specific immune response. Nevertheless, 
Lpath Inc. successfully developed monoclonal LPA antibodies via their proprietary technique, which were used in research $[144,145]$ and commercially available LPA enzyme-linked immunosorbent assay (ELISA) detecting kits (e.g.; Echelon Biosciences, T-2800s). These methods, however, have a limitation where it is not possible to distinguish individual LPA species as the ESI-MS/MS analysis does.

To overcome these obstacles, one possibility is to measure the levels of ATX, the key enzymes producing LPA [88,89], such as in the case of breast cancer and follicular lymphoma [146,147]. However, LPA levels are controlled by a complex array of enzymes and other conditions (see Section 2.2.2); therefore, ATX levels may not always correlate well to LPA levels. For example, while LPA levels are elevated in EOC [22,72-81], ATX levels are indifferent in control and EOC subjects $[77,148]$.

It may be critical to develop more direct detection methods for LPA from human samples, such as a drop of fingertip blood on a filter paper, to avoid effects derived from variations in lipid extraction and storage conditions. Direct imaging/reporter-based methods may represent another direction to bypass the sample handling related artefacts.

\subsubsection{Targeting LPA Metabolism}

As mentioned above, LPA represents a group of compounds varying in their chemical linkage to the glycerol backbone, number of carbons, and number and location of double bonds, with their molecular weights between 400 and $500 \mathrm{Da}[61,149]$. In addition, several chemically closely related compounds, including sphigosine-1 phosphate (S1P) [7,21,150,151], cyclic phosphatidic acid (cPA) [152-155], and platelet-activating factor (PAF) [156-158], as well as other lysophospholipids [7,21] share similar, distinct, or opposing signaling and functions to LPA. While this review focuses on LPA, it is important to note that these additional lipids and their strong intertwining metabolic/catabolic pathways and interactions in function make targeting LPA much more complex and challenging [71].

LPA production and catabolism are controlled by a complex network of enzymes. Extracellular LPA is mainly produced by ATX and soluble phospholipase $A_{2}$ enzymes (sPLA 2 s) [159]. Other PLA P $_{2}$ [160-166] and lipid phosphate phosphatase enzymes (LPPs) $[5,167,168]$ play important roles in LPA generation and degradation, respectively. $\mathrm{PLA}_{2} \mathrm{~S}$ are not only critical in generating the substrates for ATX to produce LPA, but they also generate LPA directly by acting on phosphatidic acid as its substrate [159-165]. To-date, among the 22 identified human PLA $\mathrm{A}_{2} \mathrm{~s}$, at least 10 were studied in cancer, with most of them being aberrantly expressed in cancer [160] (Figure 2).

LPPs are major LPA catabolic enzymes. By removing the phosphate from LPA, they inactivate most of LPA's biological effects $[5,167,168]$. Other LPA-related enzymes include several mono- or diacylglycerol kinases (MAGs and DAGs) involved in generating intracellular pools of LPA $[126,169,170]$, and lysophospholipase transacylase (LLPT) or LPA acyltransferases (LPATs) inactivating LPA by converting it to phosphatidic acid [171-173] (Figure 2).

While depletion of ATX is embryonically lethal, postnatal decreases in the expression of ATX or LPPs produce little obvious phenotypic change, suggesting less toxicity is expected when targeting these enzymes [95]. Inhibitors against ATX and LPA monoclonal antibody entered into clinical trials for fibrosis, but are yet to do so for cancer [95]. Targeting LPPs was not tested clinically, although in vitro and preclinical studies support their anti-cancer roles $[95,174]$.

At any rate, the complex array of enzymes and their regulations in LPA metabolism is a major obstacle in targeting LPA production. In addition, the enzymes shown in Figure 2 are also involved in the metabolism of other lipid molecules, further complicating the overall outcome. For example, ATX also generates cyclic phosphatidic acids (cPAs: naturally occurring analogs of LPA), which have anti-proliferative and anti-tumor activities $[175,176]$ (Figure 2).

This situation is further complicated with the involvement of the tumor microenvironment (TME), which was recently reviewed extensively $[7,95,135]$. It was shown that $\sim 40 \%$ of ATX in the body is produced by adipocytes, and this is increased further by inflammation in obesity linked to insulin resistance $[95,177]$. Cross-regulation of the immune/inflammation system, and the preferred adipose 
tissues for LPA production are emerging as critical targets for breast and multiple aggressive abdominal cancers, including colon, ovarian, and pancreatic cancers [7,95].

\section{LPA Metabolism}

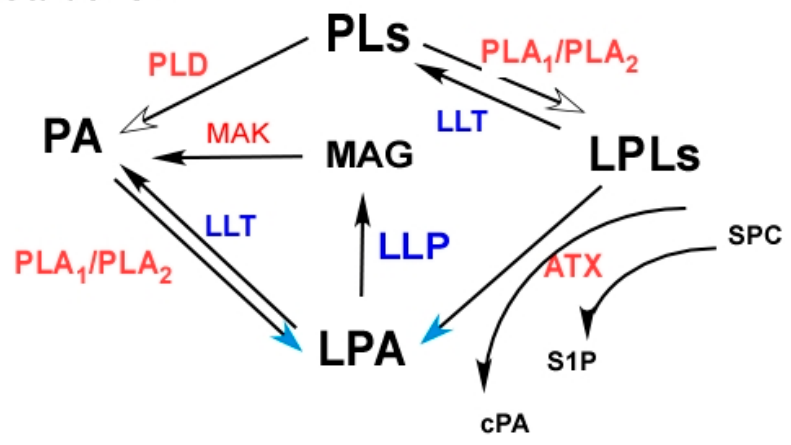

Figure 2. LPA metabolism as potential targets. Phospholipids (PLs), phosphatidic acid (PA), lysophospholipids (LPLs). The enzymes in red color, autotaxin (ATX), phospholipase $\mathrm{A}_{1}\left(\mathrm{PLA}_{2}\right)$, phospholipase D (PLD), and monoacylglycerol kinase (MAK), need to be inhibited to reduced LPA. ATX inhibitors are currently in clinical trials. The enzymes in blue, lipid phosphate phosphatase enzymes (LPPs), lysophospholipase transacylase (LLPT), or LPA acyltransferase (LPAT), need to be enhanced to increased LPA degradation. However, these enzymes are also involved in the metabolism of other lipid molecules, and the overall outcome may be complex. ATX may have multiple functions. It also produces sphingosine-1 phosphate (S1P) from sphingosylphosphorylcholine (SPC) and cyclic phosphatidic acids from lysophospholipids (LPLs). Cyclic PAs (cPAs) have anti-tumor activities [176].

\subsubsection{Targeting LPA Receptors}

GPCRs are the largest superfamily of receptors, with the identification of 865 human GPCR genes [178]. Compared to other plasma membrane receptor types with more specific ligand types, including receptor tyrosine kinases (RTKs), integrins, and ion transporters, ligands of GPCR cover very diverse chemicals, including amino acids, amine derivatives, peptides, proteins, lipid molecules, mechanical stimuli, and even ions, such as $\mathrm{Ca}^{2+}$, protons, and photons [179]. GPCRs are involved in almost all of the important physiological and many critical pathological processes. About $40 \%$ of drugs on the market act on GPCRs as agonists or antagonists [123]. The majority of LPA's tumor-promoting activities are mediated by LPA GPCR receptors, naturally making them one of the most important targets.

One of the challenges in targeting LPA GPCR receptors is their complex array of G-protein coupling, resulting in multi-faceted outcomes. While most of the other individual GPCRs, including most of the best-studied $\beta$-adrenergic receptors, neurotransmitter receptors, and sensor GPCRs (olfactory, taste, and photosensory receptors) [180-184] couple to one or two specific types of trimeric G-protein, each LPAR couples to multiple G-proteins [61]. Further studies after the review in 2014 [61] showed single G-protein coupled LPAR 6 and double G-protein coupled $\mathrm{LPAR}_{3}$ to couple to both $\mathrm{G}_{12 / 13}$ and $\mathrm{G}_{\mathrm{i}}$ for LPAR $_{6}$ [185-187] and $G_{13}$, in addition to $G_{q}$ and $G_{i}$ for LPAR 3 [188,189] (Figure 3).

Of interest, $G_{s}$ coupling is involved in many essential physiological functions, ranging from cardiovascular effects mediated by adrenergic receptors to neurotransmission by dopamine and serotonin receptors, various hormonal effects by hormone receptors, energy and inflammation regulation mediated by purinergic receptors, and skin pigmentation regulation by melanocortin receptors [184,190-197]. In particular, all olfactory GPCRs, which consist of $\sim 40 \%$ of all GPCRs in humans, are coupled to $G_{S}[180,198]$. However, $G_{S}$ in general is involved in anti-cancer activities.

While tumor-promoting activities are more consistently associated with LPAR $_{1-3}$, which are all coupled to the $\mathrm{G}_{\mathrm{i}} / \mathrm{Ras} / \mathrm{MAPK}$ pathway [61], $\mathrm{LPAR}_{4-6}$ predominantly show anti-tumor activities. For example, in colon cancer cells, $\mathrm{LPAR}_{1}$ and $\mathrm{LPAR}_{6}$ positively and negatively regulate colony formation, respectively [199]. $\mathrm{LPAR}_{4}$ reduces cell proliferation, motility, and invasiveness in head 
and neck squamous cells [200]. In pancreatic cancer cells, downregulation of LPAR 4 and $\mathrm{LPAR}_{5}$ enhanced the cell motility and colony formation activities [201]. LPAR 5 inhibited the cell motility activity of sarcoma and endothelial cells [202]. These inhibitory effects are most likely associated with the predominate ability of $\mathrm{LPAR}_{4-6}$-mediated cAMP elevation via $\mathrm{G}_{\mathrm{s}}$-coupling (such as in the case of $\mathrm{LPAR}_{4}$ and $\mathrm{LPAR}_{6}$ ) or a potentially $\mathrm{G}_{\mathrm{s}}$-independent pathway to increase cAMP via LPAR [149]. Contradictory effects of $\mathrm{LPAR}_{5}$ were also shown to enhance cell proliferation and motility in rat lung and liver cancer cells [203], which may be related to its ability to couple to $G_{q}$ and/or $G_{12 / 13}$ [61]. On the other hand, the inhibitory effects of $\mathrm{LPAR}_{5}$ in cytotoxic $\mathrm{T}$ cells may actually have a pro-tumorigenic effect [204] (Figure 3).

Many LPA GPCR receptor agonists and antagonists were developed [61]. However, most, if not all, of them have cross-activities on more than one LPA receptor or other target [61], potentially complicating the outcomes using these inhibitors. Different LPARs are differentially expressed in different cancers and different individuals. In addition, the existence of non-GPCR LPA receptors, such as PPAR $\gamma$, also needs to be considered. Studies using inhibitors against $\mathrm{LPAR}_{1}, \mathrm{LPAR}_{1 / 3}$, ATX, and LPA monoclonal antibodies recently entered clinical trials for fibrosis [95]. Cancer treatment using these reagents may be expected in the near future. However, more specific targeting of the particular tumor promoting LPAR(s) on an individual cancer and person-based manner is likely to be critical to make this targeting clinically beneficial.

As mentioned above, there are many different species of LPAs, which have preferences to bind to different LPA receptors. For example, $\mathrm{LPAR}_{3}$ preferentially binds to LPA with unsaturated fatty acids $[51,205]$. In addition, LPA GPCR receptors were shown to have ligands in addition to LPAs. For example, peptone (protein hydrolysates) and farnesyl pyrophosphate are agonists for LPAR . $^{2}$ GPR35 is a receptor for a number of naturally occurring lipids, including kynurenic 2-arachidonoyl LPA and lysophosphatidylinositol $[126,149]$. These issues are under-investigated, but may play significant roles in clinical practice.

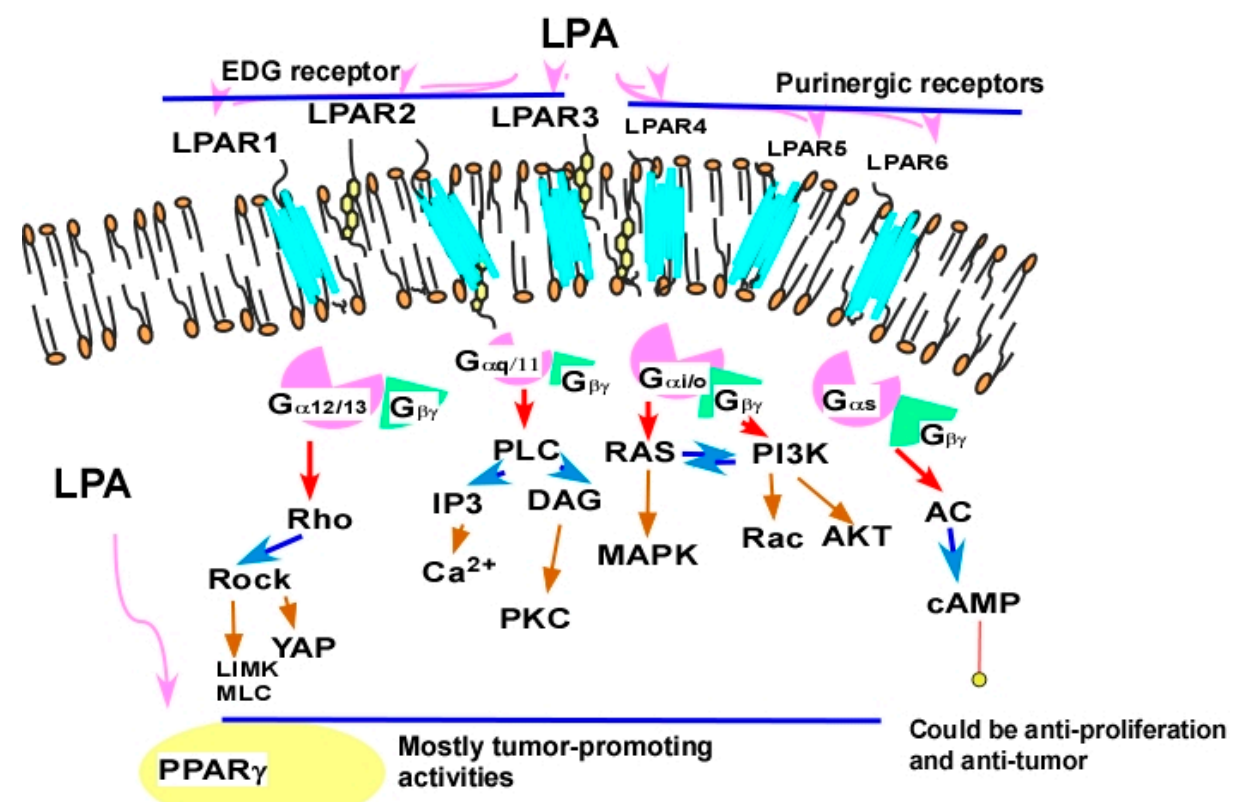

Figure 3. LPA receptors as targets. In general, the EDG family LPA receptors ( $\mathrm{LPAR}_{1-3}$ ) are coupled to $\mathrm{G}_{\mathrm{i}}, \mathrm{G}_{\mathrm{q}}$, and $\mathrm{G}_{12 / 13}$ proteins $[61,189]$ and are more involved in tumor-promoting activities. The purinergic family LPA receptors (LPAR $4-6$ ) are all coupled to $\mathrm{G}_{12 / 13}$ and other trimeric proteins [61,185-187]. Their anti-tumor effects may be mediated by their ability to elevate cyclic adenosine monophosphate (cAMP) levels [149]. 


\subsubsection{Targeting LPA Cross-Talk}

\subsubsection{Cross-Talk between LPA Signaling and Other Cell Signaling Receptors}

LPA elicits multiple and complex signaling pathways, which were extensively reviewed in recent years $[21,31,48,61,95,206-209]$. LPA signaling pathways intertwine with almost all other major cell signaling pathways. We postulate that this network, instead of an individual LPA signaling pathway, represents a more effective target. Hence, this review focuses on LPA cross-talk with other signaling molecules. These molecules are often more "targetable" with FDA-approved inhibitors in clinical trials.

The cross-talk between LPA and other signaling molecules was extensively demonstrated, covering virtually every type of cell plasma membrane receptors, including ligand-gated ion channels, receptor tyrosine kinases (RTKs), receptors with other enzymatic activities (serine or serine/threonine kinases and guanylyl cyclase enzymatic activities), other GPCRs, integrins, cytokine receptors, and T- and B-cell receptors, as well as intracellular receptors, such as PPAR $\gamma$. Listed below are examples from these categories (Figure 4).

LPA stimulates and regulates several ion channels, including the $\mathrm{Ca}^{2+}$ and $\mathrm{Ca}^{2+}$-activated potassium channels, and the $\mathrm{Na}^{+} / \mathrm{H}^{+}$exchanger 3 (NHE3) via the $\mathrm{LPAR}_{5}$ receptor, which also involves the epidermal growth factor receptor (EGFR) [210,211]. LPA also regulates glucose transporters in skeletal muscle and adipose tissue [212]. We recently showed that LPA upregulates ZIP4 (a zinc transporter) expression mainly via PPAR $\gamma$ [133] (Figure 4).

The cross-talk between receptor tyrosine kinase (RTK)-GPCR signal complexes is a focal point for the study of integration of cell signaling, which plays an important role in signal transduction [213]. The cross-talk between LPA and EGFR is the best studied [214-219]. LPA also regulates and/or transactivates platelet derived growth factor receptor (PDGFR) [220-224], tropomyosin receptor kinase A (TrkA), the receptors for nerve growth factor (NGF) [225], Toll-like receptors [226], and c-Met, the receptor for hepatocyte growth factor [227].

LPA inhibits the natriuretic peptide-induced generation of cGMP via a non-receptor tyrosine kinase Csk [228-230]. The best example of LPA's effect on non-membrane receptors is its functions with regard to Src family kinases [231-234]. In addition, LPA regulates cytokines, such as IL-6, and its downstream signal transducers and activators of transcription (Stat) signaling molecules [235].

LPA interacts with other GPCR receptors. Free fatty-acid receptors (FFARs; FFA1 and FFA4) have a potential negative cross-talk between LPA receptors and EGF receptors $[217,236]$. LPA stimulates endothelin (a GPCR ligand) expression and production in vascular smooth muscle cells [237]. In addition, a cross-talk between the LPAR-G $13 / \mathrm{p} 115 \mathrm{RhoGEF} / \mathrm{RhoA}$ pathway and the $\beta 2$-adrenergic receptor/ $\mathrm{G}_{\mathrm{s}} /$ adenylyl cyclase pathway was reported [238]. LPA also cross-talks with $\alpha 1$ adrenoceptors [239]. At physiological concentrations, LPA is capable of modulating opioid receptor binding [240].

There are close interactions between two oncogenic lysolipids, LPA and S1P, in their overlapping signaling pathways and/or directly in their receptors [241]. These two lipids can also cross-talk via ATX [242,243]. Transforming growth factor beta (TGF $\beta$ ) may play a role in the LPA-S1P cross-talk [244]. LPA upregulated expression of the cyclin-dependent kinase inhibitor p21(Waf1) in a TGF $\beta$-dependent manner [245]. Cross-talk between TNF- $\alpha$ and LPA results in the amplification of COX-2 protein expression via a conserved protein kinase D (PKD)-dependent signaling pathway [246]. Hisano et al. used a genome-wide CRISPR/dCas9-based GPCR signaling screen to identify that $\mathrm{LPAR}_{1}$ is an inducer of $\mathrm{S}_{1 P R} / \beta$-arrestin coupling. This interaction promotes the porous junctional architecture of sinus-lining lymphatic endothelial cells and enables efficient lymphocyte trafficking [247]. The functional link between LPA and integrins was established. Active integrin $\beta 1$ is required for migration of fibroblastic cells [248]. Laminin, but not other extracellular matrix proteins, induces LPA production in ovarian cancer cells via a $\beta$-integrin [164]. LPA induces $\alpha v \beta 6$-integrin-mediated TGF $\beta$ activation via the $\mathrm{LPAR}_{2}$ and the small $\mathrm{G}_{\mathrm{q}}$ [249]. LPA upregulates integrins [250,251], and integrin signaling regulates the nuclear localization and function of the $\mathrm{LPAR}_{1}$ in mammalian cells [252]. Moreover, LPA-induced 
RhoA activation integrates the functions of integrins $[251,253]$ and integrin $\alpha 6 \beta 4$ promotes expression of ATX in breast cancer cells [254]. Most noticeably, ATX directly binds to several integrins [91,255], producing LPA close to the cell membrane [256] (Figure 4).

$\mathrm{LPAR}_{5}$ functions as an inhibitory receptor able to negatively regulate T-cell receptor (TCR) signaling [204]. LPAR $_{5}$ also inhibits B-cell receptor (BCR) signal transduction via a $G_{\alpha 12 / 13} /$ Arhgef1 pathway [257]. On the other hand, LPA augments IL-13 secretion from T cells via induction of submaximal T-cell activation [258].

The cross-talk can be mono- or bidirectional and can be either positive or negative cross-talk, dependent on the type of interaction, the cell types, and the biological effects involved [259]. For example, while LPA transactivates nerve growth factor signaling via the TrkA receptor, the latter also uses a G-protein-mediated mechanism to regulate the p42/p44 MAPK pathway [260]. The bidirectional regulation between LPA and integrins is mentioned above (Figure 4).

It is important to note that LPA is involved in several stem cell/cancer stem cell (CSC) signaling pathways. The ATX-LPA signaling pathway is recognized as a critical new player in CSC [48]. LPA is involved in classical stemness pathways, such as the Wnt, Notch, and Hippo pathways [189,261-265].

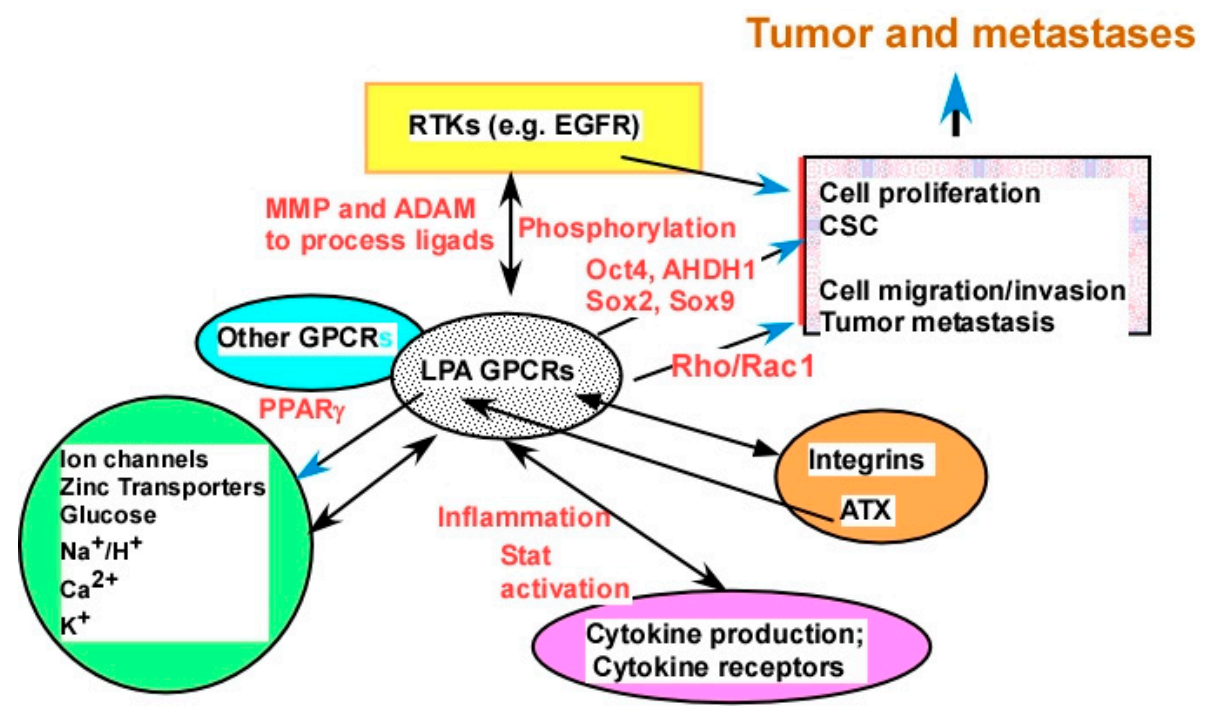

Figure 4. LPA cross-talk as potential targets. LPA interacts with major types of plasma membrane receptors, including ion channels, metal ion transporters, other transporters, receptor tyrosine kinases (RTKs), other GPCRs, integrins, and cytokine receptors. Examples from each category of receptors are discussed in the Section 2.2.4. Certain potential mechanisms of cross-talk are presented by words in red, including ligand production and/or processing, receptor phosphorylation, and production of downstream molecules mediating the cross-talk.

\subsubsection{The Molecular Mechanisms of LPA Cross-Talks}

LPA cross-talks with other signaling molecules at many different levels with divergent mechanisms. Firstly, interactions are through direct binding/interactions. Homo- and heterodimerization of LPA/S1P receptors, ovarian cancer G protein coupled receptor-1 (OGR1) and GPR4, was shown using LacZ complementation assays [266]. LPA receptors form homo- and heterodimers within the LPA receptor subgroup and heterodimers with other receptors, such as S1PR $\mathrm{S}_{1-3}$ and GPR4. Interestingly, it was shown that LPA remarkably enhances, through the $\mathrm{LPAR}_{1} / \mathrm{G}_{i}$ protein, the OGR1-mediated vascular actions to acidic $\mathrm{pH}$ [267]. These results suggest that targeting dimerization may be an effective way to block the signaling mediated by the receptors. Although GPCR dimerization was known for many years, this is an under-investigated area and warrants further investigation [266] (Figure 4).

Secondly, transactivation is mediated via enzymatic activities regulating phosphorylation and/or ligand processing. LPA induces EGF receptor transactivation through metalloproteinase (MMP) and 
a disintegrin and metalloproteinase (ADAM)-catalyzed membrane shedding of heparin-binding EGF and autocrine/paracrine activation of EGF [231,268,269], and EGF can also modulate LPAR 1 function and the phosphorylation state [268] (Figure 4).

Thirdly, an LPA-regulated transcriptome is involved. LPA regulates many cytokines, including IL-6, IL-8, growth-regulated oncogene (GRO)- $\alpha[19,20,270,271]$, and cytokine leukemia inhibitory factor (LIF) [241]. IL-6 mediates the LPA cross-talk between stromal and epithelial prostate cancer cells [272]. LPA-induced macrophage migration inhibitory factor (MIF) promotes both tumor cell growth and angiogenesis via both the Ras/MAPK and Ras-Akt/PI3K signaling pathways [273]. IL-6 exerts its biological activities through two molecules: IL-6R (IL-6 receptor) and gp130 [274]. Moreover, gp130-mediated Janus kinase (JAK)/signal transducer and activation of transcription 3 (STAT3) is required for ATX expression in adipocytes [177] (Figure 4). LPA stimulates the expression of CSC-associated genes, including OCT4, SOX2, SOX9, ALDH1, and drug transporters $[133,275,276]$, with most of these gene products being functionally involved in CSC.

Fourthly, downstream signaling pathway interactions play important roles. The signaling pathways involved in LPA cross-talk include, but are not limited to the PI3K/Ras [277], the mitogen-activated protein kinase (MAP kinase) [277,278], the focal adhesion [119], the Wnt, integrin, the Rho/Rock, and the YAP pathways [279,280], reactive oxygen species (ROS), the DNA repair pathway, and the glycolytic pathway [27], as well as the Rho-cAMP interaction [281] (Figure 4).

Finally, other signaling molecules may regulate metabolic enzymes for LPA and other lipid molecules. Neurotransmitters, cytokines, and growth factors regulate the activity of a key set of lipid-metabolizing enzymes, such as phospholipases, to affect LPA and other lipid signaling molecules [282]. In addition, an acylglycerol kinase that produces LPA modulates cross-talk with EGFR in prostate cancer cells [283].

The targeting of one or more of these cross-talks and/or the major LPA downstream signaling pathways may be critical and/or more efficient than targeting LPA or LPAR directly. For example, the FDA recently approved the first PI3K inhibitor for breast cancer treatment. The challenges are identifying one or more driver targets at the level of individual cancer type and individual patient.

\subsubsection{Targeting Tumor-Stromal Interactions in the TME}

Targeting the tumor-prone microenvironment gained increasing attention in recent years [7]. Although ATX can be produced directly by cancer cells, such as in melanomas, glioblastomas, and thyroid tumors [95], it may be mainly produced by stroma cells, as $\sim 40 \%$ of ATX in the body is produced by adipocytes, and this is increased further by inflammation in obesity linked to insulin resistance [95]. In addition, macrophage-derived phospholipase $\mathrm{A}_{2}\left(\mathrm{PLA}_{2}\right)$, which is a soluble PLA produces extracellular LPA and is involved in EOC and associated with early relapse of EOC [284,285] (Figure 5).

While S1P's functions in the immune system were extensively studied, and the S1P receptor axis represents an obligatory signal for trafficking of immune cells [34], the role of LPA in the immune system is less studied [34]. LPA affects TCR and BCR as mentioned in Section 2.2.4.1, and LPA converts monocytes into macrophages in both mice and humans [286] (Figure 5). In addition, ATX represents a connecting point for both S1P and LPA, since it is an enzyme producing both S1P and LPA [287]. More interestingly, a recent study showed that S1P/S1PR4 and ATX/LPA/LPAR 5,6 appear as critical axes for immune infiltrates [34]. These were robust differences in sphingolipid/LPA-related checkpoints and the drug response. Genes including CD68 (a monocyte/macrophage marker), $L P A R_{3}$ (a LPA receptor), $S M P D 1$ (sphingomyelin phosphodiesterase 1 that converts sphingomyelin to ceramide), PPAP2B (LPP3, a phosphatidic acid phosphatase, converting phosphatidic acid to diacylglycerol and LPA to monoacylglecerol [288]), and SMPD2 (sphingomyelin phosphodiesterase 2, with lysophospholipase activity) emerged as the most prognostically important markers. In particular, alignment of data across a variety of malignancies (over 600 different neoplasm categories) revealed specific preference for ovarian carcinoma [34]. It is interesting that ATX, $\mathrm{LPAR}_{1}$, and $\mathrm{LPAR}_{5}$ are higher in the immune-high 
tumor (Cd14-, Cd68-, Cd164-, and Cd3E-high) group, but LPAR 2.3 are higher in the immune-low group [34], suggesting the complex regulatory roles of the ATX-LPA axis in the tumor-immune system interaction.

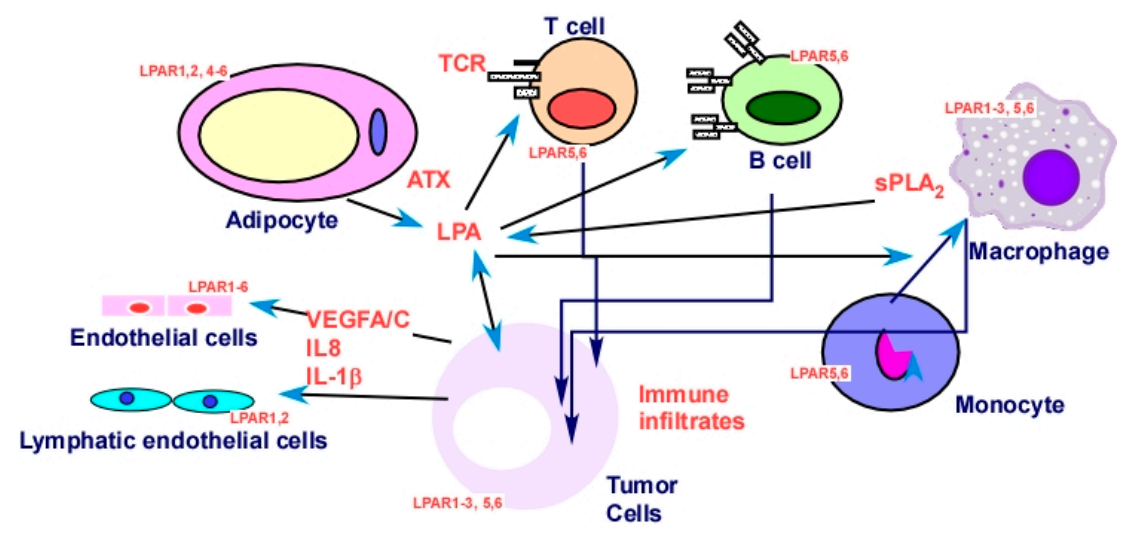

Figure 5. LPA in tumor cells and in the tumor microenvironment (TME). Tumor, stromal, and immune cells in the TME express LPA receptors, and they produce and/or respond to LPA $[34,119,185,202,247,256,289-294]$. The overall effects produce a tumor-promoting environment as detailed in Section 2.2.5 and in recent reviews [7,21,135].

\section{Conclusions}

While LPA and/or the ATX-LPA axis are generally accepted as important targets for cancer, we are still facing several major obstacles to move targeting to clinical practice as presented above. Personalized medicine is now well accepted conceptually to treat highly heterogenic diseases, such as cancers. The complex LPA metabolism, its receptor, and its signaling systems suggest that detecting signatures/networks, rather than individual gene/protein/lipid expression, from individual patients will likely become necessary to develop effective treatments for highly heterogenic diseases, such as cancer. Bioinformatics/systems biological analyses become very important to achieve such goals, which provide unprecedented scale and depth of knowledge and perspectives in cancer research, as well as directions for translational and clinical applications. These studies use multi-modular integrative approaches consolidating large amount of data from gene expression profiling, next-generation sequencing, -omics studies, prognostic/predictive modeling, and functional studies for cancer $[295,296]$. The most prominent example is the Pan-cancer Atlas analyses organized by the National Institute of Health (NIH), which is based on The Cancer Genome Atlas (TCGA) data of over 11,000 tumors from 33 of the most prevalent forms of cancer, using comprehensive, in-depth, and interconnected bioinformatics analyses (https://www.cell.com/pb-assets/consortium/ pancanceratlas/pancani3/index.html?code=cell-site). One such study related to LPA identified novel sphingolipid-LPA immune checkpoints and networks underlying tumor immune heterogeneity and disease outcomes, as mentioned in the Section 2.2.5 [34]. This type of study holds great promise for delivering novel stratifying and targeting strategies [34].

It is important to note that, although targeting LPA signaling appears to be an attractive approach for cancer treatment, it is unlikely that this will be effective as monotherapy. One of the major challenges in LPA targeting will be to discover the magic modalities to be effective in cancer treatment, which are likely to be different for different cancers and even for different individuals. Synthetic lethality studies led to the clinical benefits of using poly (ADP-ribose) polymerase (PARP) inhibitors in OC and other cancers, which is a very significant step forward in the field [297]. Similar studies are urgently needed for LPA targeting through logical and empirical screening. As an interesting note, accumulated data suggest that LPA is a very strong inducer for cell migration, invasion, and tumor metastasis, but a rather weak proliferation stimulus $[4,23,25]$. On the other hand, growth factors, such as EGF and insulin growth receptor (IGF), possess strong cell proliferation, but rather weak chemotactic activities. 
Proper combinational inhibition of these two sets of critical activities in cancer cells simultaneously may represent an effective strategy (Figure 4). Both in vitro and in vivo studies in these areas are highly needed to move the field forward.

Taken together, although we are still facing a number of obstacles, the large body of data generated from the last 3-4 decades from thousands of papers provided solid evidence and rationale to target the LPA network. Rapid development of biotechnological tools for analyses of LPA, as well as its functions and mechanisms, and for processing the vast amount of data provided and will continue to furnish essentials for the field to leap ahead and eventually improve patient outcomes.

Author Contributions: Writing-review and editing, Y.X.

Funding: This research received no external funding.

Acknowledgments: The author would like to thank Kevin McClelland for editing the manuscript.

Conflicts of Interest: The author declares no conflict of interest.

\section{References}

1. Hanahan, D.; Weinberg, R.A. The hallmarks of cancer. Cell 2000, 100, 57-70. [CrossRef]

2. Hanahan, D.; Weinberg, R.A. Hallmarks of cancer: The next generation. Cell 2011, 144, 646-674. [CrossRef] [PubMed]

3. Mills, G.B.; Moolenaar, W.H. The emerging role of lysophosphatidic acid in cancer. Nat. Rev. Cancer 2003, 3, 582-591. [CrossRef] [PubMed]

4. Sengupta, S.; Wang, Z.; Tipps, R.; Xu, Y. Biology of LPA in health and disease. Semin. Cell Dev. Biol. 2004, 15, 503-512. [CrossRef] [PubMed]

5. Leblanc, R.; Peyruchaud, O. New insights into the autotaxin/LPA axis in cancer development and metastasis. Exp. Cell Res. 2015, 333, 183-189. [CrossRef] [PubMed]

6. Jesionowska, A.; Cecerska-Heryc, E.; Marczuk, N.; Safranow, K.; Dolegowska, B. Lysophosphatidic acid and malignant neoplasms. Postepy Biochem. 2015, 61, 381-387.

7. $\mathrm{Xu}, \mathrm{Y}$. Lysophospholipid Signaling in the Epithelial Ovarian Cancer Tumor Microenvironment. Cancers 2018, 10, 227. [CrossRef]

8. Xu, Y.; Gaudette, D.C.; Boynton, J.D.; Frankel, A.; Fang, X.J.; Sharma, A.; Hurteau, J.; Casey, G.; Goodbody, A.; Mellors, A.; et al. Characterization of an ovarian cancer activating factor in ascites from ovarian cancer patients. Clin. Cancer Res. 1995, 1, 1223-1232.

9. Xu, Y.; Casey, G.; Mills, G.B. Effect of lysophospholipids on signaling in the human Jurkat T cell line. J. Cell. Physiol. 1995, 163, 441-450. [CrossRef]

10. Xu, Y.; Fang, X.J.; Casey, G.; Mills, G.B. Lysophospholipids activate ovarian and breast cancer cells. Biochem. J. 1995, 309, 933-940. [CrossRef]

11. Deng, W.; Wang, D.A.; Gosmanova, E.; Johnson, L.R.; Tigyi, G. LPA protects intestinal epithelial cells from apoptosis by inhibiting the mitochondrial pathway. Am. J. Physiol. Gastrointest. Liver Physiol. 2003, 284, 821-829. [CrossRef] [PubMed]

12. Sui, Y.; Yang, Y.; Wang, J.; Li, Y.; Ma, H.; Cai, H.; Liu, X.; Zhang, Y.; Wang, S.; Li, Z.; et al. Lysophosphatidic acid Inhibits apoptosis induced by cisplatin in cervical cancer cells. Biomed. Res. Int. 2015, 2015, e598386. [CrossRef] [PubMed]

13. Bermudez, Y.; Yang, H.; Saunders, B.O.; Cheng, J.Q.; Nicosia, S.V.; Kruk, P.A. VEGF- and LPA-induced telomerase in human ovarian cancer cells is Sp1-dependent. Gynecol. Oncol. 2007, 106, 526-537. [CrossRef] [PubMed]

14. Sako, A.; Kitayama, J.; Shida, D.; Suzuki, R.; Sakai, T.; Ohta, H.; Nagawa, H. Lysophosphatidic acid (LPA)-induced vascular endothelial growth factor (VEGF) by mesothelial cells and quantification of host-derived VEGF in malignant ascites. J. Surg. Res. 2006, 130, 94-101. [CrossRef] [PubMed]

15. Lin, C.I.; Chen, C.N.; Huang, M.T.; Lee, S.J.; Lin, C.H.; Chang, C.C.; Lee, H. Lysophosphatidic acid upregulates vascular endothelial growth factor- $C$ and tube formation in human endothelial cells through LPA(1/3), COX-2, and NF-kappaB activation- and EGFR transactivation-dependent mechanisms. Cell. Signal. 2008, 20, 1804-1814. [CrossRef] [PubMed] 
16. Lin, C.H.; Lu, J.; Lee, H. Interleukin-1beta expression is required for lysophosphatidic Acid-induced lymphangiogenesis in human umbilical vein endothelial cells. Int. J. Inflam. 2010, 2011, e351010.

17. Lin, Y.C.; Chen, C.C.; Chen, W.M.; Lu, K.Y.; Shen, T.L.; Jou, Y.C.; Shen, C.H.; Ohbayashi, N.; Kanaho, Y.; Huang, Y.L.; et al. LPA1/3 signaling mediates tumor lymphangiogenesis through promoting CRT expression in prostate cancer. Biochim. Biophys. Acta Mol. Cell Biol. Lipids 2018, 1863, 1305-1315. [CrossRef]

18. Wu, P.Y.; Lin, Y.C.; Huang, Y.L.; Chen, W.-M.; Chen, C.-C.; Lee, H.L. Mechanisms of lysophosphatidic acid-mediated lymphangiogenesis in prostate cancer. Cancers 2018, 10, 413. [CrossRef]

19. Schwartz, B.M.; Hong, G.; Morrison, B.H.; Wu, W.; Baudhuin, L.M.; Xiao, Y.J.; Mok, S.C.; Xu, Y. Lysophospholipids increase interleukin-8 expression in ovarian cancer cells. Gynecol. Oncol. 2001, 81, 291-300. [CrossRef]

20. Fang, X.; Yu, S.; Bast, R.C.; Liu, S.; Xu, H.J.; Hu, S.X.; LaPushin, R.; Claret, F.X.; Aggarwal, B.B.; Lu, Y.; et al. Mechanisms for lysophosphatidic acid-induced cytokine production in ovarian cancer cells. J. Biol. Chem. 2004, 279, 9653-9661. [CrossRef]

21. Hisano, Y.; Hla, T. Bioactive lysolipids in cancer and angiogenesis. Pharmacol. Ther. 2019, 193, 91-98. [CrossRef] [PubMed]

22. Sutphen, R.; Xu, Y.; Wilbanks, G.D.; Fiorica, J.; Grendys, E.C., Jr.; LaPolla, J.P.; Arango, H.; Hoffman, M.S.; Martino, M.; Wakeley, K.; et al. Lysophospholipids are potential biomarkers of ovarian cancer. Cancer Epidemiol. Biomark. Prev. 2004, 13, 1185-1191.

23. Kim, K.S.; Sengupta, S.; Berk, M.; Kwak, Y.G.; Escobar, P.F.; Belinson, J.; Mok, S.C.; Xu, Y. Hypoxia enhances lysophosphatidic acid responsiveness in ovarian cancer cells and lysophosphatidic acid induces ovarian tumor metastasis in vivo. Cancer Res. 2006, 66, 7983-7990. [CrossRef] [PubMed]

24. Ren, J.; Xiao, Y.J.; Singh, L.S.; Zhao, X.; Zhao, Z.; Feng, L.; Rose, T.M.; Prestwich, G.D.; Xu, Y. Lysophosphatidic acid is constitutively produced by human peritoneal mesothelial cells and enhances adhesion, migration, and invasion of ovarian cancer cells. Cancer Res. 2006, 66, 3006-3014. [CrossRef]

25. Sengupta, S.; Kim, K.S.; Berk, M.P.; Oates, R.; Escobar, P.; Belinson, J.; Li, W.; Lindner, D.J.; Williams, B.; Xu, Y. Lysophosphatidic acid downregulates tissue inhibitor of metalloproteinases, which are negatively involved in lysophosphatidic acid-induced cell invasion. Oncogene 2007, 26, 2894-2901. [CrossRef]

26. Liu, S.; Umezu-Goto, M.; Murph, M.; Lu, Y.; Liu, W.; Zhang, F.; Yu, S.; Stephens, L.C.; Cui, X.; Murrow, G.; et al. Expression of autotaxin and lysophosphatidic acid receptors increases mammary tumorigenesis, invasion, and metastases. Cancer Cell 2009, 15, 539-550. [CrossRef]

27. Cholia, R.P.; Dhiman, M.; Kumar, R.; Mantha, A.K. Oxidative stress stimulates invasive potential in rat C6 and human U-87 MG glioblastoma cells via activation and cross-talk between PKM2, ENPP2 and APE1 enzymes. Metab. Brain Dis. 2018, 33, 1307-1326. [CrossRef]

28. Balogh, A.; Shimizu, Y.; Lee, S.C.; Norman, D.D.; Gangwar, R.; Bavaria, M.; Moon, C.; Shukla, P.; Rao, R.; Ray, R.; et al. The autotaxin-LPA2 GPCR axis is modulated by gamma-irradiation and facilitates DNA damage repair. Cell. Signal. 2015, 27, 1751-1762. [CrossRef]

29. Barekzi, E.; Roman, J.; Hise, K.; Georas, S.; Steinke, J.W. Lysophosphatidic acid stimulates inflammatory cascade in airway epithelial cells. Prostaglandins Leukot. Essent. Fatty Acids 2006, 74, 357-363. [CrossRef]

30. Spangelo, B.L.; Jarvis, W.D. Lysophosphatidylcholine stimulates interleukin-6 release from rat anterior pituitary cells in vitro. Endocrinology 1996, 137, 4419-4426. [CrossRef]

31. Jesionowska, A.; Cecerska-Heryc, E.; Matoszka, N.; Dolegowska, B. Lysophosphatidic acid signaling in ovarian cancer. J. Recept. Signal. Transduct. Res. 2015, 35, 578-584. [CrossRef] [PubMed]

32. D'Souza, K.; Nzirorera, C.; Cowie, A.M.; Varghese, G.P.; Trivedi, P.; Eichmann, T.O.; Biswas, D.; Touaibia, M.; Morris, A.J.; Aidinis, V.; et al. Autotaxin-LPA signaling contributes to obesity-induced insulin resistance in muscle and impairs mitochondrial metabolism. J. Lipid Res. 2018, 59, 1805-1817. [CrossRef] [PubMed]

33. Ha, J.H.; Radhakrishnan, R.; Jayaraman, M.; Yan, M.; Ward, J.D.; Fung, K.M.; Moxley, K.; Sood, A.K.; Isidoro, C.; Mukherjee, P.; et al. LPA Induces Metabolic Reprogramming in Ovarian Cancer via a Pseudohypoxic Response. Cancer Res. 2018, 78, 1923-1934. [CrossRef] [PubMed]

34. Meshcheryakova, A.; Svoboda, M.; Jaritz, M.; Mungenast, F.; Salzmann, M.; Pils, D.; Cacsire Castillo-Tong, D.; Hager, G.; Wolf, A.; Braicu, E.I.; et al. Interrelations of Sphingolipid and Lysophosphatidate Signaling with Immune System in Ovarian Cancer. Comput. Struct. Biotechnol. J. 2019, 17, 537-560. [CrossRef] [PubMed]

35. Moolenaar, W.H. LPA: A novel lipid mediator with diverse biological actions. Trends Cell Biol. 1994, 4, 213-219. [CrossRef] 
36. Contos, J.J.; Ishii, I.; Chun, J. Lysophosphatidic acid receptors. Mol. Pharmacol. 2000, 58, 1188-1196. [CrossRef]

37. Fang, X.; Schummer, M.; Mao, M.; Yu, S.; Tabassam, F.H.; Swaby, R.; Hasegawa, Y.; Tanyi, J.L.; LaPushin, R.; Eder, A.; et al. Lysophosphatidic acid is a bioactive mediator in ovarian cancer. Biochim. Biophys. Acta 2002, 1582, 257-264. [CrossRef]

38. Goetzl, E.J.; Graeler, M.; Huang, M.C.; Shankar, G. Lysophospholipid growth factors and their G protein-coupled receptors in immunity, coronary artery disease, and cancer. Sci. World J. 2002, 2, 324-338. [CrossRef]

39. Mills, G.B.; Eder, A.; Fang, X.; Hasegawa, Y.; Mao, M.; Lu, Y.; Tanyi, J.; Tabassam, F.H.; Wiener, J.; Lapushin, R.; et al. Critical role of lysophospholipids in the pathophysiology, diagnosis, and management of ovarian cancer. Cancer Treat. Res. 2002, 107, 259-283.

40. Tokumura, A. Physiological and pathophysiological roles of lysophosphatidic acids produced by secretory lysophospholipase D in body fluids. Biochim. Biophys. Acta 2002, 1582, 18-25. [CrossRef]

41. Xu, Y.; Xiao, Y.J.; Zhu, K.; Baudhuin, L.M.; Lu, J.; Hong, G.; Kim, K.S.; Cristina, K.L.; Song, L.; Williams, F.S. Unfolding the pathophysiological role of bioactive lysophospholipids. Curr. Drug Targets Immune Endocr. Metabol. Disord. 2003, 3, 23-32. [CrossRef] [PubMed]

42. Aoki, J. Mechanisms of lysophosphatidic acid production. Semin. Cell Dev. Biol. 2004, 15, 477-489. [CrossRef] [PubMed]

43. Pua, T.L.; Wang, F.Q.; Fishman, D.A. Roles of LPA in ovarian cancer development and progression. Future Oncol. 2009, 5, 1659-1673. [CrossRef] [PubMed]

44. Tabuchi, S. The autotaxin-lysophosphatidic acid-lysophosphatidic acid receptor cascade: Proposal of a novel potential therapeutic target for treating glioblastoma multiforme. Lipids Health Dis. 2015, 14, e56. [CrossRef]

45. Bar-Shavit, R.; Maoz, M.; Kancharla, A.; Nag, J.K.; Agranovich, D.; Grisaru-Granovsky, S.; Uziely, B. G Protein-Coupled Receptors in Cancer. Int. J. Mol. Sci. 2016, 17, 1320. [CrossRef]

46. Benesch, M.G.; Tang, X.; Venkatraman, G.; Bekele, R.T.; Brindley, D.N. Recent advances in targeting the autotaxin-lysophosphatidate-lipid phosphate phosphatase axis in vivo. J. Biomed. Res. 2016, 30, 272-284.

47. Benesch, M.G.K.; MacIntyre, I.T.K.; McMullen, T.P.W.; Brindley, D.N. Coming of Age for Autotaxin and Lysophosphatidate Signaling: Clinical Applications for Preventing, Detecting and Targeting Tumor-Promoting Inflammation. Cancers 2018, 10, e73. [CrossRef]

48. Lee, D.; Suh, D.S.; Lee, S.C.; Tigyi, G.J.; Kim, J.H. Role of autotaxin in cancer stem cells. Cancer Metastasis Rev. 2018, 37, 509-518. [CrossRef]

49. Yun, C.C. Lysophosphatidic Acid and Autotaxin-associated Effects on the Initiation and Progression of Colorectal Cancer. Cancers 2019, 11, 958. [CrossRef]

50. Kirschner, H.; Vogt, W. Pharmacologically active lipidsoluble acids in brain extracts: Isolation of lysophosphatidic acid and ganglioside. Biochem. Pharmacol. 1961, 8, 224-234. [CrossRef]

51. Chan, L.C.; Peters, W.; Xu, Y.; Chun, J.; Farese, R.V., Jr.; Cases, S. LPA3 receptor mediates chemotaxis of immature murine dendritic cells to unsaturated lysophosphatidic acid (LPA). J. Leukoc. Biol. 2007, 82, 1193-1200. [CrossRef] [PubMed]

52. Liu, S.; Murph, M.; Panupinthu, N.; Mills, G.B. ATX-LPA receptor axis in inflammation and cancer. Cell Cycle 2009, 8, 3695-3701. [CrossRef] [PubMed]

53. Van Corven, E.J.; Groenink, A.; Jalink, K.; Eichholtz, T.; Moolenaar, W.H. Lysophosphatidate-induced cell proliferation: Identification and dissection of signaling pathways mediated by G proteins. Cell 1989, 59, 45-54. [CrossRef]

54. Jalink, K.; van Corven, E.J.; Moolenaar, W.H. Lysophosphatidic acid, but not phosphatidic acid, is a potent $\mathrm{Ca} 2(+)$-mobilizing stimulus for fibroblasts. Evidence for an extracellular site of action. J. Biol. Chem. 1990, 265, 12232-12239. [PubMed]

55. Moolenaar, W.H.; van Corven, E.J. Growth factor-like action of lysophosphatidic acid: Mitogenic signalling mediated by G proteins. Ciba Found. Symp. 1990, 72, e99.

56. Moolenaar, W.H. Mitogenic action of lysophosphatidic acid. Adv. Cancer Res. 1991, 57, 87-102.

57. Jalink, K.; Eichholtz, T.; Postma, F.R.; van Corven, E.J.; Moolenaar, W.H. Lysophosphatidic acid induces neuronal shape changes via a novel, receptor-mediated signaling pathway: Similarity to thrombin action. Cell Growth Differ. 1993, 4, 247-255.

58. Jalink, K.; Moolenaar, W.H.; Van Duijn, B. Lysophosphatidic acid is a chemoattractant for Dictyostelium discoideum amoebae. Proc. Natl. Acad Sci. USA 1993, 90, 1857-1861. [CrossRef] 
59. Van Corven, E.J.; Hordijk, P.L.; Medema, R.H.; Bos, J.L.; Moolenaar, W.H. Pertussis toxin-sensitive activation of p21ras by G protein-coupled receptor agonists in fibroblasts. Proc. Natl. Acad. Sci. USA 1993, 90, 1257-1261. [CrossRef]

60. Weiner, J.A.; Hecht, J.H.; Chun, J. Lysophosphatidic acid receptor gene vzg-1/lpA1/edg-2 is expressed by mature oligodendrocytes during myelination in the postnatal murine brain. J. Comp. Neurol. 1998, 398, 587-598. [CrossRef]

61. Yung, Y.C.; Stoddard, N.C.; Chun, J. LPA receptor signaling: Pharmacology, physiology, and pathophysiology. J. Lipid Res. 2014, 55, 1192-1214. [CrossRef] [PubMed]

62. Chun, J.; Goetzl, E.J.; Hla, T.; Igarashi, Y.; Lynch, K.R.; Moolenaar, W.; Pyne, S.; Tigyi, G. International Union of Pharmacology. XXXIV. Lysophospholipid receptor nomenclature. Pharmacol. Rev. 2002, 54, 265-269. [CrossRef] [PubMed]

63. An, S.; Bleu, T.; Huang, W.; Hallmark, O.G.; Coughlin, S.R.; Goetzl, E.J. Identification of cDNAs encoding two G protein-coupled receptors for lysosphingolipids. FEBS Lett. 1997, 417, 279-282. [CrossRef]

64. An, S.; Bleu, T.; Hallmark, O.G.; Goetzl, E.J. Characterization of a novel subtype of human G protein-coupled receptor for lysophosphatidic acid. J. Biol. Chem. 1998, 273, 7906-7910. [CrossRef] [PubMed]

65. Bandoh, K.; Aoki, J.; Hosono, H.; Kobayashi, S.; Kobayashi, T.; Murakami-Murofushi, K.; Tsujimoto, M.; Arai, H.; Inoue, K. Molecular cloning and characterization of a novel human G-protein-coupled receptor, EDG7, for lysophosphatidic acid. J. Biol. Chem. 1999, 274, 27776-27785. [CrossRef] [PubMed]

66. Yanagida, K.; Ishii, S.; Hamano, F.; Noguchi, K.; Shimizu, T. LPA4/p2y9/GPR23 mediates rho-dependent morphological changes in a rat neuronal cell line. J. Biol. Chem. 2007, 282, 5814-5824. [CrossRef] [PubMed]

67. Kotarsky, K.; Boketoft, A.; Bristulf, J.; Nilsson, N.E.; Norberg, A.; Hansson, S.; Owman, C.; Sillard, R.; Leeb-Lundberg, L.M.; Olde, B. Lysophosphatidic acid binds to and activates GPR92, a G protein-coupled receptor highly expressed in gastrointestinal lymphocytes. J. Pharmacol. Exp. Ther. 2006, 318, 619-628. [CrossRef] [PubMed]

68. Lee, C.W.; Rivera, R.; Gardell, S.; Dubin, A.E.; Chun, J. GPR92 as a new G12/13- and Gq-coupled lysophosphatidic acid receptor that increases cAMP, LPA5. J. Biol. Chem. 2006, 281, 23589-23597. [CrossRef]

69. Pasternack, S.M.; von Kugelgen, I.; Al Aboud, K.; Lee, Y.A.; Ruschendorf, F.; Voss, K.; Hillmer, A.M.; Molderings, G.J.; Franz, T.; Ramirez, A.; et al. G protein-coupled receptor P2Y5 and its ligand LPA are involved in maintenance of human hair growth. Nat. Genet. 2008, 40, 329-334. [CrossRef]

70. Yanagida, K.; Masago, K.; Nakanishi, H.; Kihara, Y.; Hamano, F.; Tajima, Y.; Taguchi, R.; Shimizu, T.; Ishii, S. Identification and characterization of a novel lysophosphatidic acid receptor, p2y5/LPA6. J. Biol. Chem. 2009, 284, 17731-17741. [CrossRef]

71. Kihara, Y.; Maceyka, M.; Spiegel, S.; Chun, J. Lysophospholipid receptor nomenclature review: IUPHAR Review 8. Br. J. Pharmacol. 2014, 171, 3575-3594. [CrossRef] [PubMed]

72. Xu, Y.; Shen, Z.; Wiper, D.W.; Wu, M.; Morton, R.E.; Elson, P.; Kennedy, A.W.; Belinson, J.; Markman, M.; Casey, G. Lysophosphatidic acid as a potential biomarker for ovarian and other gynecologic cancers. JAMA 1998, 280, 719-723. [CrossRef] [PubMed]

73. Xiao, Y.; Chen, Y.; Kennedy, A.W.; Belinson, J.; Xu, Y. Evaluation of plasma lysophospholipids for diagnostic significance using electrospray ionization mass spectrometry (ESI-MS) analyses. Ann. N. Y. Acad. Sci. 2000, 905, 242-259. [CrossRef] [PubMed]

74. Sedlakova, I.; Vavrova, J.; Tosner, J.; Hanousek, L. Lysophosphatidic acid in ovarian cancer patients. Ceska Gynekol. 2006, 71, 312-317. [CrossRef] [PubMed]

75. Meleh, M.; Pozlep, B.; Mlakar, A.; Meden-Vrtovec, H.; Zupancic-Kralj, L. Determination of serum lysophosphatidic acid as a potential biomarker for ovarian cancer. J. Chromatogr. B Analyt. Technol. Biomed. Life Sci. 2007, 858, 287-291. [CrossRef] [PubMed]

76. Sedlakova, I.; Vavrova, J.; Tosner, J.; Hanousek, L. Lysophosphatidic acid: An ovarian cancer marker. Eur. J. Gynaecol. Oncol. 2008, 29, 511-514. [PubMed]

77. Nakamura, K.; Igarashi, K.; Ohkawa, R.; Yokota, H.; Masuda, A.; Nakagawa, S.; Yano, T.; Ikeda, H.; Aoki, J.; Yatomi, Y. Serum autotaxin is not a useful biomarker for ovarian cancer. Lipids 2012, 47, 927-930. [CrossRef] [PubMed]

78. Lu, Z.; Chen, Y.; Hu, Z.; Hu, C. Diagnostic value of total plasma lysophosphatidic acid in ovarian cancer: A meta-analysis. Int. J. Gynecol Cancer 2015, 25, 18-23. [CrossRef] [PubMed] 
79. Zhang, Y.J.; Cao, L.Y.; Fu, Z.Z.; Wang, Y.J.; Wang, G.X.; Gu, T. Clinical significance of plasma lysophosphatidic acid levels in the differential diagnosis of ovarian cancer. J. Cancer Res. Ther. 2015, 11, 375-380. [CrossRef]

80. Li, Y.Y.; Zhang, W.C.; Zhang, J.L.; Zheng, C.J.; Zhu, H.; Yu, H.M.; Fan, L.M. Plasma levels of lysophosphatidic acid in ovarian cancer versus controls: A meta-analysis. Lipids Health Dis. 2015, 14, e72. [CrossRef]

81. Moore, R.G.; Blackman, A.; Miller, M.C.; Robison, K.; DiSilvestro, P.A.; Eklund, E.E.; Strongin, R.; Messerlian, G. Multiple biomarker algorithms to predict epithelial ovarian cancer in women with a pelvic mass: Can additional makers improve performance? Gynecol. Oncol. 2019, 154, 150-155. [CrossRef] [PubMed]

82. Zeng, R.; Li, B.; Huang, J.; Zhong, M.; Li, L.; Duan, C.; Zeng, S.; Huang, J.; Liu, W.; Lu, J.; et al. Lysophosphatidic Acid is a Biomarker for Peritoneal Carcinomatosis of Gastric Cancer and Correlates with Poor Prognosis. Genet. Test. Mol. Biomark. 2017, 21, 641-648. [CrossRef] [PubMed]

83. Xiao, Y.J.; Schwartz, B.; Washington, M.; Kennedy, A.; Webster, K.; Belinson, J.; Xu, Y. Electrospray ionization mass spectrometry analysis of lysophospholipids in human ascitic fluids: Comparison of the lysophospholipid contents in malignant vs nonmalignant ascitic fluids. Anal. Biochem. 2001, 290, 302-313. [CrossRef] [PubMed]

84. Liebisch, G.; Scherer, M. Quantification of bioactive sphingo- and glycerophospholipid species by electrospray ionization tandem mass spectrometry in blood. J. Chromatogr. B Analyt. Technol. Biomed. Life Sci. 2012, 883-884, 141-146. [CrossRef] [PubMed]

85. Zhao, Z.; Xu, Y. Measurement of endogenous lysophosphatidic acid by ESI-MS/MS in plasma samples requires pre-separation of lysophosphatidylcholine. J. Chromatogr. B Analyt. Technol. Biomed. Life Sci. 2009, 877, 3739-3742. [CrossRef] [PubMed]

86. Zhao, Z.; Xu, Y. An extremely simple method for extraction of lysophospholipids and phospholipids from blood samples. J. Lipid Res. 2010, 51, 652-659. [CrossRef] [PubMed]

87. Jesionowska, A.; Cecerska, E.; Dolegowska, B. Methods for quantifying lysophosphatidic acid in body fluids: A review. Anal. Biochem. 2014, 453, 38-43. [CrossRef] [PubMed]

88. Umezu-Goto, M.; Kishi, Y.; Taira, A.; Hama, K.; Dohmae, N.; Takio, K.; Yamori, T.; Mills, G.B.; Inoue, K.; Aoki, J.; et al. Autotaxin has lysophospholipase D activity leading to tumor cell growth and motility by lysophosphatidic acid production. J. Cell Biol. 2002, 158, 227-233. [CrossRef]

89. Tokumura, A.; Majima, E.; Kariya, Y.; Tominaga, K.; Kogure, K.; Yasuda, K.; Fukuzawa, K. Identification of human plasma lysophospholipase D, a lysophosphatidic acid-producing enzyme, as autotaxin, a multifunctional phosphodiesterase. J. Biol. Chem. 2002, 277, 39436-39442. [CrossRef]

90. Inoue, K.; Tanaka, N.; Haga, A.; Yamasaki, K.; Umeda, T.; Kusakabe, Y.; Sakamoto, Y.; Nonaka, T.; Deyashiki, Y.; Nakamura, K.T. Crystallization and preliminary X-ray crystallographic analysis of human autotaxin. Acta Crystallogr. Sect. F Struct. Biol. Cryst. Commun. 2011, 67, 450-453. [CrossRef]

91. Hausmann, J.; Kamtekar, S.; Christodoulou, E.; Day, J.E.; Wu, T.; Fulkerson, Z.; Albers, H.M.; van Meeteren, L.A.; Houben, A.J.; van Zeijl, L.; et al. Structural basis of substrate discrimination and integrin binding by autotaxin. Nat. Struct. Mol. Biol. 2011, 18, 198-204. [CrossRef] [PubMed]

92. Nishimasu, H.; Okudaira, S.; Hama, K.; Mihara, E.; Dohmae, N.; Inoue, A.; Ishitani, R.; Takagi, J.; Aoki, J.; Nureki, O. Crystal structure of autotaxin and insight into GPCR activation by lipid mediators. Nat. Struct. Mol. Biol. 2011, 18, 205-212. [CrossRef] [PubMed]

93. Chrencik, J.E.; Roth, C.B.; Terakado, M.; Kurata, H.; Omi, R.; Kihara, Y.; Warshaviak, D.; Nakade, S.; Asmar-Rovira, G.; Mileni, M.; et al. Crystal Structure of Antagonist Bound Human Lysophosphatidic Acid Receptor 1. Cell 2015, 161, 1633-1643. [CrossRef] [PubMed]

94. Taniguchi, R.; Inoue, A.; Sayama, M.; Uwamizu, A.; Yamashita, K.; Hirata, K.; Yoshida, M.; Tanaka, Y.; Kato, H.E.; Nakada-Nakura, Y.; et al. Structural insights into ligand recognition by the lysophosphatidic acid receptor LPA6. Nature 2017, 548, 356-360. [CrossRef] [PubMed]

95. Benesch, M.G.K.; Yang, Z.; Tang, X.; Meng, G.; Brindley, D.N. Lysophosphatidate Signaling: The Tumor Microenvironment's New Nemesis. Trends Cancer 2017, 3, 748-752. [CrossRef] [PubMed]

96. Tokumura, A.; Fukuzawa, K.; Isobe, J.; Tsukatani, H. Lysophosphatidic acid-induced aggregation of human and feline platelets: Structure-activity relationship. Biochem. Biophys. Res. Commun. 1981, 99, 391-398. [CrossRef]

97. Tokumura, A.; Kume, T.; Fukuzawa, K.; Tsukatani, H. Cardiovascular effects of lysophosphatidic acid and its structural analogs in rats. J. Pharmacol. Exp. Ther. 1981, 219, 219-224. [PubMed] 
98. Tokumura, A.; Mostafa, M.H.; Nelson, D.R.; Hanahan, D.J. Stimulation of $\left(\mathrm{Ca}^{+}+\mathrm{Mg}^{+}\right)$-ATPase activity in human erythrocyte membranes by synthetic lysophosphatidic acids and lysophosphatidylcholines. Effects of chain length and degree of unsaturation of the fatty acid groups. Biochim. Biophys. Acta 1985, 812, 568-574. [CrossRef]

99. Nugent, D.; Xu, Y. Sphingosine-1-phosphate: Characterization of its inhibition of platelet aggregation. Platelets 2000, 11, 226-232. [PubMed]

100. Sato, A.; Nakazawa, K.; Sugawara, A.; Yamazaki, Y.; Ebina, K. The interaction of beta 2 -glycoprotein I with lysophosphatidic acid in platelet aggregation and blood clotting. Biochim. Biophys. Acta Proteins Proteom. 2018, 1866, 1232-1241. [CrossRef] [PubMed]

101. Gerrard, J.M.; Kindom, S.E.; Peterson, D.A.; Peller, J.; Krantz, K.E.; White, J.G. Lysophosphatidic acids. Influence on platelet aggregation and intracellular calcium flux. Am. J. Pathol. 1979, 96, 423-438. [PubMed]

102. Mauco, G.; Chap, H.; Simon, M.F.; Douste-Blazy, L. Phosphatidic and lysophosphatidic acid production in phospholipase C-and thrombin-treated platelets. Possible involvement of a platelet lipase. Biochimie 1978, 60, 653-661. [CrossRef]

103. Lapetina, E.G.; Billah, M.M.; Cuatrecasas, P. Lysophosphatidic acid potentiates the thrombin-induced production of arachidonate metabolites in platelets. J. Biol. Chem. 1981, 256, 11984-11987. [PubMed]

104. Oyesanya, R.A.; Lee, Z.P.; Wu, J.; Chen, J.; Song, Y.; Mukherjee, A.; Dent, P.; Kordula, T.; Zhou, H.; Fang, X. Transcriptional and post-transcriptional mechanisms for lysophosphatidic acid-induced cyclooxygenase-2 expression in ovarian cancer cells. FASEB J. 2008, 22, 2639-2651. [CrossRef] [PubMed]

105. Watsky, M.A. Lysophosphatidic acid, serum, and hyposmolarity activate Cl- currents in corneal keratocytes. Am. J. Physiol. 1995, 269, 1385-1393. [CrossRef] [PubMed]

106. Yang, L.; Andrews, D.A.; Low, P.S. Lysophosphatidic acid opens a $\mathrm{Ca}(++)$ channel in human erythrocytes. Blood 2000, 95, 2420-2425. [PubMed]

107. Juarez-Contreras, R.; Rosenbaum, T.; Morales-Lazaro, S.L. Lysophosphatidic Acid and Ion Channels as Molecular Mediators of Pain. Front. Mol. Neurosci. 2018, 11, e462. [CrossRef] [PubMed]

108. MacIntyre, D.E.; Shaw, A.M. Phospholipid-induced human platelet activation: Effects of calcium channel blockers and calcium chelators. Thromb. Res. 1983, 31, 833-844. [CrossRef]

109. Petrou, S.; Ordway, R.W.; Hamilton, J.A.; Walsh, J.V., Jr.; Singer, J.J. Structural requirements for charged lipid molecules to directly increase or suppress $\mathrm{K}+$ channel activity in smooth muscle cells. Effects of fatty acids, lysophosphatidate, acyl coenzyme A and sphingosine. J. Gen. Physiol. 1994, 103, 471-486. [CrossRef] [PubMed]

110. Hernandez-Araiza, I.; Morales-Lazaro, S.L.; Canul-Sanchez, J.A.; Islas, L.D.; Rosenbaum, T. Role of lysophosphatidic acid in ion channel function and disease. J. Neurophysiol. 2018, 120, 1198-1211. [CrossRef] [PubMed]

111. Tokumura, A.; Fukuzawa, K.; Tsukatani, H. Effects of synthetic and natural lysophosphatidic acids on the arterial blood pressure of different animal species. Lipids 1978, 13, 572-574. [CrossRef] [PubMed]

112. Mark, K.; Bragg, B.; Chawla, K.; Hladky, K. Medical abortion in women with large uterine fibroids: A case series. Contraception 2016, 94, 572-574. [CrossRef] [PubMed]

113. Xu, Y.J.; Aziz, O.A.; Bhugra, P.; Arneja, A.S.; Mendis, M.R.; Dhalla, N.S. Potential role of lysophosphatidic acid in hypertension and atherosclerosis. Can. J. Cardiol. 2003, 19, 1525-1536. [PubMed]

114. Tokumura, A.; Yube, N.; Fujimoto, H.; Tsukatani, H. Lysophosphatidic acids induce contraction of rat isolated colon by two different mechanisms. J. Pharm. Pharmacol. 1991, 43, 774-778. [CrossRef] [PubMed]

115. Koschel, K.; Tas, P.W. Lysophosphatidic acid reverts the beta-adrenergic agonist-induced morphological response in C6 rat glioma cells. Exp. Cell Res. 1993, 206, 162-166. [CrossRef] [PubMed]

116. Chettibi, S.; Lawrence, A.J.; Stevenson, R.D.; Young, J.D. Effect of lysophosphatidic acid on motility, polarisation and metabolic burst of human neutrophils. FEMS Immunol. Med. Microbiol. 1994, 8, 271-281. [CrossRef] [PubMed]

117. Hill, C.S.; Oh, S.Y.; Schmidt, S.A.; Clark, K.J.; Murray, A.W. Lysophosphatidic acid inhibits gap-junctional communication and stimulates phosphorylation of connexin- 43 in WB cells: Possible involvement of the mitogen-activated protein kinase cascade. Biochem. J. 1994, 303 Pt 2, 475-479. [CrossRef]

118. Zhang, C.; Lambert, M.P.; Bunch, C.; Barber, K.; Wade, W.S.; Krafft, G.A.; Klein, W.L. Focal adhesion kinase expressed by nerve cell lines shows increased tyrosine phosphorylation in response to Alzheimer's A beta peptide. J. Biol. Chem. 1994, 269, 25247-25250. 
119. Seufferlein, T.; Rozengurt, E. Lysophosphatidic acid stimulates tyrosine phosphorylation of focal adhesion kinase, paxillin, and p130. Signaling pathways and cross-talk with platelet-derived growth factor. J. Biol. Chem. 1994, 269, 9345-9351.

120. Schimmel, R.J.; Honeyman, T.W.; McMahon, K.K.; Serio, R.; Clark, R.B. Inhibition of cyclic AMP accumulation in hamster adipocytes with phosphatidic acid: Differences and similarities with alpha adrenergic effects. J. Cycl. Nucleotide Res. 1980, 6, 437-449.

121. Gerrard, J.M.; Beattie, L.L.; McCrae, J.M.; Singhroy, S. The influence of lysophosphatidic acid on platelet protein phosphorylation. Biochem. Cell Biol. 1987, 65, 642-650. [CrossRef] [PubMed]

122. Ridley, A.J.; Hall, A. The small GTP-binding protein rho regulates the assembly of focal adhesions and actin stress fibers in response to growth factors. Cell 1992, 70, 389-399. [CrossRef]

123. Howard, A.D.; McAllister, G.; Feighner, S.D.; Liu, Q.; Nargund, R.P.; Van der Ploeg, L.H.; Patchett, A.A. Orphan G-protein-coupled receptors and natural ligand discovery. Trends Pharmacol. Sci. 2001, 22, 132-140. [CrossRef]

124. Tabata, K.; Baba, K.; Shiraishi, A.; Ito, M.; Fujita, N. The orphan GPCR GPR87 was deorphanized and shown to be a lysophosphatidic acid receptor. Biochem. Biophys. Res. Commun. 2007, 363, 861-866. [CrossRef] [PubMed]

125. Ochiai, S.; Furuta, D.; Sugita, K.; Taniura, H.; Fujita, N. GPR87 mediates lysophosphatidic acid-induced colony dispersal in A431 cells. Eur. J. Pharmacol. 2013, 715, 15-20. [CrossRef] [PubMed]

126. Zhao, P.; Abood, M.E. GPR55 and GPR35 and their relationship to cannabinoid and lysophospholipid receptors. Life Sci. 2013, 92, 453-457. [CrossRef] [PubMed]

127. Murakami, M.; Shiraishi, A.; Tabata, K.; Fujita, N. Identification of the orphan GPCR, P2Y(10) receptor as the sphingosine-1-phosphate and lysophosphatidic acid receptor. Biochem. Biophys. Res. Commun. 2008, 371, 707-712. [CrossRef]

128. McIntyre, T.M.; Pontsler, A.V.; Silva, A.R.; St Hilaire, A.; Xu, Y.; Hinshaw, J.C.; Zimmerman, G.A.; Hama, K.; Aoki, J.; Arai, H.; et al. Identification of an intracellular receptor for lysophosphatidic acid (LPA): LPA is a transcellular PPARgamma agonist. Proc. Natl. Acad. Sci. USA 2003, 100, 131-136. [CrossRef]

129. Tsukahara, T. The Role of PPARgamma in the Transcriptional Control by Agonists and Antagonists. PPAR Res. 2012, 2012, e362361. [CrossRef]

130. Tsukahara, T. PPAR gamma Networks in Cell Signaling: Update and Impact of Cyclic Phosphatidic Acid. J. Lipids 2013, 2013, e246597. [CrossRef]

131. Crowder, M.K.; Seacrist, C.D.; Blind, R.D. Phospholipid regulation of the nuclear receptor superfamily. Adv. Biol. Regul. 2017, 63, 6-14. [CrossRef] [PubMed]

132. Yousefnia, S.; Momenzadeh, S.; Seyed Forootan, F.; Ghaedi, K.; Nasr Esfahani, M.H. The influence of peroxisome proliferator-activated receptor gamma (PPARgamma) ligands on cancer cell tumorigenicity. Gene 2018, 649, 14-22. [CrossRef] [PubMed]

133. Fan, Q.; Cai, Q.; Li, P.; Wang, W.; Wang, J.; Gerry, E.; Wang, T.L.; Shih, I.M.; Nephew, K.P.; Xu, Y. The novel ZIP4 regulation and its role in ovarian cancer. Oncotarget 2017, 8, 90090-90107. [CrossRef] [PubMed]

134. Tokumura, A.; Harada, K.; Fukuzawa, K.; Tsukatani, H. Involvement of lysophospholipase D in the production of lysophosphatidic acid in rat plasma. Biochim. Biophys. Acta 1986, 875, 31-38.

135. Tigyi, G.J.; Yue, J.; Norman, D.D.; Szabo, E.; Balogh, A.; Balazs, L.; Zhao, G.; Lee, S.C. Regulation of tumor cell-Microenvironment interaction by the autotaxin-lysophosphatidic acid receptor axis. Adv. Biol. Regul. 2019, 71, 183-193. [CrossRef]

136. Blaho, V.A.; Chun, J. 'Crystal' clear? lysophospholipid receptor structure insights and controversies. Trends Pharmacol Sci. 2018, 39, 953-966. [CrossRef]

137. Chun, J. Lysophospholipid receptors: Implications for neural signaling. Crit. Rev. Neurobiol. 1999, 13, 151-168. [CrossRef]

138. Moolenaar, W.H.; Houben, A.J.; Lee, S.J.; van Meeteren, L.A. Autotaxin in embryonic development. Biochim. Biophys. Acta 2013, 1831, 13-19. [CrossRef]

139. Ye, X.; Chun, J. Lysophosphatidic acid (LPA) signaling in vertebrate reproduction. Trends Endocrinol. Metab. 2010, 21, 17-24. [CrossRef]

140. Murph, M.; Tanaka, T.; Pang, J.; Felix, E.; Liu, S.; Trost, R.; Godwin, A.K.; Newman, R.; Mills, G. Liquid chromatography mass spectrometry for quantifying plasma lysophospholipids: Potential biomarkers for cancer diagnosis. Methods Enzymol. 2007, 433, 1-25. 
141. Yagi, T.; Shoaib, M.; Kuschner, C.; Nishikimi, M.; Becker, L.B.; Lee, A.T.; Kim, J. Challenges and Inconsistencies in Using Lysophosphatidic Acid as a Biomarker for Ovarian Cancer. Cancers 2019, 11, 520. [CrossRef] [PubMed]

142. Kennerly, D.A. Molecular species analysis of lysophospholipids using high-performance liquid chromatography and argentation thin-layer chromatography. J. Chromatogr. 1987, 409, 291-297. [CrossRef]

143. Schmidt, R.; Kunze, D.; Egger, E. Two-dimensional thin layer chromatographic separation of phosphatidic acid and lysophosphatidic acid in lipid mixtures. Z. Med. Lab. Diagn. 1978, 19, 306-311. [PubMed]

144. Fleming, J.K.; Glass, T.R.; Lackie, S.J.; Wojciak, J.M. A novel approach for measuring sphingosine-1-phosphate and lysophosphatidic acid binding to carrier proteins using monoclonal antibodies and the Kinetic Exclusion Assay. J. Lipid Res. 2016, 57, 1737-1747. [CrossRef] [PubMed]

145. Eisenried, A.; Meidahl, A.C.N.; Klukinov, M.; Tzabazis, A.Z.; Sabbadini, R.A.; Clark, J.D.; Yeomans, D.C. Nervous system delivery of antilysophosphatidic acid antibody by nasal application attenuates mechanical allodynia after traumatic brain injury in rats. Pain 2017, 158, 2181-2188. [CrossRef] [PubMed]

146. Shao, Y.; Yu, Y.; He, Y.; Chen, Q.; Liu, H. Serum ATX as a novel biomarker for breast cancer. Medicine (Baltimore) 2019, 98, e14973. [CrossRef] [PubMed]

147. Masuda, A.; Nakamura, K.; Izutsu, K.; Igarashi, K.; Ohkawa, R.; Jona, M.; Higashi, K.; Yokota, H.; Okudaira, S.; Kishimoto, T.; et al. Serum autotaxin measurement in haematological malignancies: A promising marker for follicular lymphoma. Br. J. Haematol. 2008, 143, 60-70. [CrossRef] [PubMed]

148. Tokumura, A.; Tominaga, K.; Yasuda, K.; Kanzaki, H.; Kogure, K.; Fukuzawa, K. Lack of significant differences in the corrected activity of lysophospholipase D, producer of phospholipid mediator lysophosphatidic acid, in incubated serum from women with and without ovarian tumors. Cancer 2002, 94, 141-151. [CrossRef] [PubMed]

149. Yanagida, K.; Ishii, S. Non-Edg family LPA receptors: The cutting edge of LPA research. J. Biochem. 2011, 150, 223-232. [CrossRef]

150. Zheng, X.; Li, W.; Ren, L.; Liu, J.; Pang, X.; Chen, X.; Kang, D.; Wang, J.; Du, G. The sphingosine kinase-1/sphingosine-1-phosphate axis in cancer: Potential target for anticancer therapy. Pharmacol. Ther. 2019, 195, 85-99. [CrossRef] [PubMed]

151. Geffken, K.; Spiegel, S. Sphingosine kinase 1 in breast cancer. Adv. Biol. Regul. 2018, 67, 59-65. [CrossRef] [PubMed]

152. Friedman, P.; Haimovitz, R.; Markman, O.; Roberts, M.F.; Shinitzky, M. Conversion of lysophospholipids to cyclic lysophosphatidic acid by phospholipase D. J. Biol. Chem. 1996, 271, 953-957. [CrossRef] [PubMed]

153. Grzelczyk, A.; Koziolkiewicz, M. Cyclic phosphatidic acids and their analogues-unique lipid mediators. Postepy Biochem. 2012, 58, 327-343. [PubMed]

154. Murakami-Murofushi, K.; Uchiyama, A.; Fujiwara, Y.; Kobayashi, T.; Kobayashi, S.; Mukai, M.; Murofushi, H.; Tigyi, G. Biological functions of a novel lipid mediator, cyclic phosphatidic acid. Biochim. Biophys. Acta 2002, 1582, 1-7. [CrossRef]

155. Tsukahara, T.; Matsuda, Y.; Haniu, H. Lysophospholipid-Related Diseases and PPARgamma Signaling Pathway. Int. J. Mol. Sci. 2017, 18, 2730. [CrossRef] [PubMed]

156. Wykle, R.L.; Malone, B.; Snyder, F. Enzymatic synthesis of 1-alkyl-2-acetyl-sn-glycero-3-phosphocholine, a hypotensive and platelet-aggregating lipid. J. Biol. Chem. 1980, 255, 10256-10260. [PubMed]

157. Jancar, S.; Chammas, R. PAF receptor and tumor growth. Curr. Drug Targets 2014, 15, 982-987.

158. Tsoupras, A.B.; Iatrou, C.; Frangia, C.; Demopoulos, C.A. The implication of platelet activating factor in cancer growth and metastasis: Potent beneficial role of PAF-inhibitors and antioxidants. Infect. Disord. Drug Targets 2009, 9, 390-399. [CrossRef] [PubMed]

159. Aoki, J.; Inoue, A.; Okudaira, S. Two pathways for lysophosphatidic acid production. Biochim. Biophys. Acta 2008, 1781, 513-518. [CrossRef] [PubMed]

160. Scott, K.F.; Sajinovic, M.; Hein, J.; Nixdorf, S.; Galettis, P.; Liauw, W.; de Souza, P.; Dong, Q.; Graham, G.G.; Russell, P.J. Emerging roles for phospholipase A2 enzymes in cancer. Biochimie 2010, 92, 601-610. [CrossRef]

161. Liu, N.K.; Deng, L.X.; Zhang, Y.P.; Lu, Q.B.; Wang, X.F.; Hu, J.G.; Oakes, E.; Bonventre, J.V.; Shields, C.B.; $\mathrm{Xu}, \mathrm{X} . \mathrm{M}$. Cytosolic phospholipase A2 protein as a novel therapeutic target for spinal cord injury. Ann. Neurol. 2014, 75, 644-658. [CrossRef] [PubMed] 
162. Cai, H.; Chiorean, E.G.; Chiorean, M.V.; Rex, D.K.; Robb, B.W.; Hahn, N.M.; Liu, Z.; Loehrer, P.J.; Harrison, M.L.; $\mathrm{Xu}, \mathrm{Y}$. Elevated phospholipase A2 activities in plasma samples from multiple cancers. PLoS ONE 2013, 8, e57081. [CrossRef] [PubMed]

163. Liu, N.K.; Byers, J.S.; Lam, T.; Lu, Q.B.; Sengelaub, D.R.; Xu, X.M. Inhibition of cPLA2 has neuroprotective effects on motoneuron and muscle atrophy following spinal cord injury. J. Neurotrauma 2014. [CrossRef] [PubMed]

164. Sengupta, S.; Xiao, Y.J.; Xu, Y. A novel laminin-induced LPA autocrine loop in the migration of ovarian cancer cells. FASEB J. 2003, 17, 1570-1572. [CrossRef] [PubMed]

165. Liu, N.K.; Zhang, Y.P.; Titsworth, W.L.; Jiang, X.; Han, S.; Lu, P.H.; Shields, C.B.; Xu, X.M. A novel role of phospholipase A2 in mediating spinal cord secondary injury. Ann. Neurol. 2006, 59, 606-619. [CrossRef]

166. Shen, Z.; Belinson, J.; Morton, R.E.; Xu, Y.; Xu, Y. Phorbol 12-myristate 13-acetate stimulates lysophosphatidic acid secretion from ovarian and cervical cancer cells but not from breast or leukemia cells. Gynecol. Oncol. 1998, 71, 364-368. [CrossRef] [PubMed]

167. Leblanc, R.; Houssin, A.; Peyruchaud, O. Platelets, autotaxin and lysophosphatidic acid signalling: Win-win factors for cancer metastasis. Br. J. Pharmacol. 2018, 175, 3100-3110. [CrossRef]

168. Xu, J.; Zhang, Q.X.; Pilquil, C.; Berthiaume, L.G.; Waggoner, D.W.; Brindley, D.N. Lipid phosphate phosphatase-1 in the regulation of lysophosphatidate signaling. Ann. N. Y. Acad. Sci. 2000, 905, 81-90. [CrossRef]

169. Sakane, F.; Mizuno, S.; Takahashi, D.; Sakai, H. Where do substrates of diacylglycerol kinases come from? Diacylglycerol kinases utilize diacylglycerol species supplied from phosphatidylinositol turnover-independent pathways. Adv. Biol. Regul. 2018, 67, 101-108. [CrossRef]

170. Sato, Y.; Murakami, C.; Yamaki, A.; Mizuno, S.; Sakai, H.; Sakane, F. Distinct 1-monoacylglycerol and 2-monoacylglycerol kinase activities of diacylglycerol kinase isozymes. Biochim. Biophys. Acta 2016, 1864, 1170-1176. [CrossRef]

171. Angkawijaya, A.E.; Nguyen, V.C.; Nakamura, Y. Lysophosphatidic acid acyltransferases 4 and 5 are involved in glycerolipid metabolism and nitrogen starvation response in Arabidopsis. New Phytol. 2019, 224, 336-351. [CrossRef]

172. Sugimoto, H.; Yamashita, S. Purification, characterization, and inhibition by phosphatidic acid of lysophospholipase transacylase from rat liver. J. Biol. Chem. 1994, 269, 6252-6258. [PubMed]

173. Thompson, F.J.; Clark, M.A. Purification of a lysophosphatidic acid-hydrolysing lysophospholipase from rat brain. Biochem. J. 1994, 300, 457-461. [CrossRef] [PubMed]

174. Nakayama, J.; Raines, T.A.; Lynch, K.R.; Slack-Davis, J.K. Decreased peritoneal ovarian cancer growth in mice lacking expression of lipid phosphate phosphohydrolase 1. PLoS ONE 2015, 10, e0120071. [CrossRef] [PubMed]

175. Gendaszewska-Darmach, E. Lysophosphatidic acids, cyclic phosphatidic acids and autotaxin as promising targets in therapies of cancer and other diseases. Acta Biochim. Pol. 2008, 55, 227-240. [PubMed]

176. Tania, M.; Khan, M.A.; Zhang, H.; Li, J.; Song, Y. Autotaxin: A protein with two faces. Biochem. Biophys. Res. Commun. 2010, 401, 493-497. [CrossRef] [PubMed]

177. Sun, S.; Wang, R.; Song, J.; Guan, M.; Li, N.; Zhang, X.; Zhao, Z.; Zhang, J. Blocking gp130 signaling suppresses autotaxin expression in adipocytes and improves insulin sensitivity in diet-induced obesity. J. Lipid Res. 2017, 58, 2102-2113. [CrossRef] [PubMed]

178. Surgand, J.S.; Rodrigo, J.; Kellenberger, E.; Rognan, D. A chemogenomic analysis of the transmembrane binding cavity of human G-protein-coupled receptors. Proteins 2006, 62, 509-538. [CrossRef] [PubMed]

179. Im, D.S. Orphan G protein-coupled receptors and beyond. Jpn. J. Pharmacol. 2002, 90, 101-106. [CrossRef] [PubMed]

180. Dalesio, N.M.; Barreto Ortiz, S.F.; Pluznick, J.L.; Berkowitz, D.E. Olfactory, Taste, and Photo Sensory Receptors in Non-sensory Organs: It Just Makes Sense. Front. Physiol. 2018, 9, e1673. [CrossRef] [PubMed]

181. Wise, A.; Jupe, S.C.; Rees, S. The identification of ligands at orphan G-protein coupled receptors. Annu. Rev. Pharmacol. Toxicol. 2004, 44, 43-66. [CrossRef] [PubMed]

182. Zurawski, Z.; Yim, Y.Y.; Alford, S.; Hamm, H.E. The expanding roles and mechanisms of G protein-mediated presynaptic inhibition. J. Biol. Chem. 2019, 294, 1661-1670. [CrossRef] [PubMed]

183. McDonald, P.H.; Lefkowitz, R.J. Beta-Arrestins: New roles in regulating heptahelical receptors' functions. Cell. Signal. 2001, 13, 683-689. [CrossRef] 
184. Svoboda, P.; Teisinger, J.; Novotny, J.; Bourova, L.; Drmota, T.; Hejnova, L.; Moravcova, Z.; Lisy, V.; Rudajev, V.; Stohr, J.; et al. Biochemistry of transmembrane signaling mediated by trimeric G proteins. Physiol. Res. 2004, 53, 141-152.

185. Masago, K.; Kihara, Y.; Yanagida, K.; Hamano, F.; Nakagawa, S.; Niwa, M.; Shimizu, T. Lysophosphatidic acid receptor, LPA6, regulates endothelial blood-brain barrier function: Implication for hepatic encephalopathy. Biochem. Biophys. Res. Commun. 2018, 501, 1048-1054. [CrossRef]

186. Kano, K.; Matsumoto, H.; Inoue, A.; Yukiura, H.; Kanai, M.; Chun, J.; Ishii, S.; Shimizu, T.; Aoki, J. Molecular mechanism of lysophosphatidic acid-induced hypertensive response. Sci. Rep. 2019, 9, e2662. [CrossRef]

187. Lee, M.; Choi, S.; Hallden, G.; Yo, S.J.; Schichnes, D.; Aponte, G.W. P2Y5 is a G(alpha)i, G(alpha)12/13 G protein-coupled receptor activated by lysophosphatidic acid that reduces intestinal cell adhesion. Am. J. Physiol. Gastrointest. Liver Physiol. 2009, 297, 641-654. [CrossRef]

188. Fan, Q.; Cai, Q.; Xu, Y. FOXM1 is a downstream target of LPA and YAP oncogenic signaling pathways in high grade serous ovarian cancer. Oncotarget 2015, 6, 27688-27699. [CrossRef]

189. Cai, H.; Xu, Y. The role of LPA and YAP signaling in long-term migration of human ovarian cancer cells. Cell Commun. Signal. 2013, 11, e31. [CrossRef]

190. Gurevich, E.V.; Gainetdinov, R.R.; Gurevich, V.V. G protein-coupled receptor kinases as regulators of dopamine receptor functions. Pharmacol. Res. 2016, 111, 1-16. [CrossRef]

191. Spiegel, A.M. Hormone resistance caused by mutations in G proteins and G protein-coupled receptors. J. Pediatr. Endocrinol. Metab. 1999, 12, 303-309. [PubMed]

192. Gardella, T.J.; Vilardaga, J.P. International Union of Basic and Clinical Pharmacology. XCIII. The parathyroid hormone receptors-family B G protein-coupled receptors. Pharmacol. Rev. 2015, 67, 310-337. [CrossRef]

193. Filardo, E.J.; Thomas, P. Minireview: G protein-coupled estrogen receptor-1, GPER-1: Its mechanism of action and role in female reproductive cancer, renal and vascular physiology. Endocrinology 2012, 153, 2953-2962. [CrossRef] [PubMed]

194. Wolf Horrell, E.M.; Boulanger, M.C.; D'Orazio, J.A. Melanocortin 1 Receptor: Structure, Function, and Regulation. Front. Genet. 2016, 7, e95. [CrossRef] [PubMed]

195. Marangos, P.J.; Boulenger, J.P. Basic and clinical aspects of adenosinergic neuromodulation. Neurosci. Biobehav. Rev. 1985, 9, 421-430. [CrossRef]

196. Hamblin, M.W.; Guthrie, C.R.; Kohen, R.; Heidmann, D.E. Gs protein-coupled serotonin receptors: Receptor isoforms and functional differences. Ann. N. Y. Acad. Sci. 1998, 861, 31-37. [CrossRef] [PubMed]

197. Srinivasan, S.; Vaisse, C.; Conklin, B.R. Engineering the melanocortin-4 receptor to control G(s) signaling in vivo. Ann. N. Y. Acad Sci. 2003, 994, 225-232. [CrossRef] [PubMed]

198. Malnic, B.; Godfrey, P.A.; Buck, L.B. The human olfactory receptor gene family. Proc. Natl. Acad. Sci. USA 2004, 101, 2584-2589. [CrossRef] [PubMed]

199. Takahashi, K.; Fukushima, K.; Otagaki, S.; Ishimoto, K.; Minami, K.; Fukushima, N.; Honoki, K.; Tsujiuchi, T. Effects of LPA1 and LPA6 on the regulation of colony formation activity in colon cancer cells treated with anticancer drugs. J. Recept. Signal. Transduct. Res. 2018, 38, 71-75. [CrossRef]

200. Matayoshi, S.; Chiba, S.; Lin, Y.; Arakaki, K.; Matsumoto, H.; Nakanishi, T.; Suzuki, M.; Kato, S. Lysophosphatidic acid receptor 4 signaling potentially modulates malignant behavior in human head and neck squamous cell carcinoma cells. Int. J. Oncol. 2013, 42, 1560-1568. [CrossRef] [PubMed]

201. Ishii, S.; Hirane, M.; Fukushima, K.; Tomimatsu, A.; Fukushima, N.; Tsujiuchi, T. Diverse effects of LPA4, LPA5 and LPA6 on the activation of tumor progression in pancreatic cancer cells. Biochem. Biophys. Res. Commun. 2015, 461, 59-64. [CrossRef] [PubMed]

202. Araki, M.; Kitayoshi, M.; Dong, Y.; Hirane, M.; Ozaki, S.; Mori, S.; Fukushima, N.; Honoki, K.; Tsujiuchi, T. Inhibitory effects of lysophosphatidic acid receptor-5 on cellular functions of sarcoma cells. Growth Factors 2014, 32, 117-122. [CrossRef] [PubMed]

203. Okabe, K.; Hayashi, M.; Yamawaki, Y.; Teranishi, M.; Honoki, K.; Mori, T.; Fukushima, N.; Tsujiuchi, T. Possible involvement of lysophosphatidic acid receptor-5 gene in the acquisition of growth advantage of rat tumor cells. Mol. Carcinog. 2011, 50, 635-642. [CrossRef] [PubMed]

204. Mathew, D.; Kremer, K.N.; Strauch, P.; Tigyi, G.; Pelanda, R.; Torres, R.M. LPA5 Is an Inhibitory Receptor That Suppresses CD8 T-Cell Cytotoxic Function via Disruption of Early TCR Signaling. Front. Immunol. 2019, 10, e1159. [CrossRef] [PubMed] 
205. Bandoh, K.; Aoki, J.; Taira, A.; Tsujimoto, M.; Arai, H.; Inoue, K. Lysophosphatidic acid (LPA) receptors of the EDG family are differentially activated by LPA species. Structure-activity relationship of cloned LPA receptors. FEBS Lett. 2000, 478, 159-165. [CrossRef]

206. Okudaira, S.; Yukiura, H.; Aoki, J. Biological roles of lysophosphatidic acid signaling through its production by autotaxin. Biochimie 2010, 92, 698-706. [CrossRef] [PubMed]

207. Tsujiuchi, T.; Araki, M.; Hirane, M.; Dong, Y.; Fukushima, N. Lysophosphatidic acid receptors in cancer pathobiology. Histol. Histopathol. 2014, 29, 313-321. [PubMed]

208. Yung, Y.C.; Stoddard, N.C.; Mirendil, H.; Chun, J. Lysophosphatidic Acid signaling in the nervous system. Neuron 2015, 85, 669-682. [CrossRef]

209. Zhou, Y.; Little, P.J.; Ta, H.T.; Xu, S.; Kamato, D. Lysophosphatidic acid and its receptors: Pharmacology and therapeutic potential in atherosclerosis and vascular disease. Pharmacol. Ther. 2019. [CrossRef]

210. No, Y.R.; He, P.; Yoo, B.K.; Yun, C.C. Regulation of NHE3 by lysophosphatidic acid is mediated by phosphorylation of NHE3 by RSK2. Am. J. Physiol. Cell Physiol. 2015, 309, 14-21. [CrossRef]

211. Kouba, S.; Ouldamer, L.; Garcia, C.; Fontaine, D.; Chantome, A.; Vandier, C.; Goupille, C.; Potier-Cartereau, M. Lipid metabolism and Calcium signaling in epithelial ovarian cancer. Cell Calcium. 2019, 81, 38-50. [CrossRef] [PubMed]

212. Song, X.; Zheng, X.; Malbon, C.C.; Wang, H. Galpha i2 enhances in vivo activation of and insulin signaling to GLUT4. J. Biol. Chem. 2001, 276, 34651-34658. [CrossRef] [PubMed]

213. Pyne, N.J.; Waters, C.; Moughal, N.A.; Sambi, B.S.; Pyne, S. Receptor tyrosine kinase-GPCR signal complexes. Biochem. Soc. Trans. 2003, 31, 1220-1225. [CrossRef] [PubMed]

214. Boerner, J.L.; Biscardi, J.S.; Silva, C.M.; Parsons, S.J. Transactivating agonists of the EGF receptor require Tyr 845 phosphorylation for induction of DNA synthesis. Mol. Carcinog. 2005, 44, 262-273. [CrossRef]

215. Obara, Y.; Okano, Y.; Ono, S.; Yamauchi, A.; Hoshino, T.; Kurose, H.; Nakahata, N. Betagamma subunits of G(i/o) suppress EGF-induced ERK5 phosphorylation, whereas ERK1/2 phosphorylation is enhanced. Cell. Signal. 2008, 20, 1275-1283. [CrossRef]

216. Wang, Z. Transactivation of Epidermal Growth Factor Receptor by G Protein-Coupled Receptors: Recent Progress, Challenges and Future Research. Int. J. Mol. Sci. 2016, 17, 95. [CrossRef] [PubMed]

217. Hopkins, M.M.; Liu, Z.; Meier, K.E. Positive and Negative Cross-Talk between Lysophosphatidic Acid Receptor 1, Free Fatty Acid Receptor 4, and Epidermal Growth Factor Receptor in Human Prostate Cancer Cells. J. Pharmacol. Exp. Ther. 2016, 359, 124-133. [CrossRef]

218. Harper, K.; Lavoie, R.R.; Charbonneau, M.; Brochu-Gaudreau, K.; Dubois, C.M. The Hypoxic Tumor Microenvironment Promotes Invadopodia Formation and Metastasis through LPA1 Receptor and EGFR Cooperation. Mol. Cancer Res. 2018, 16, 1601-1613. [CrossRef]

219. Gschwind, A.; Prenzel, N.; Ullrich, A. Lysophosphatidic acid-induced squamous cell carcinoma cell proliferation and motility involves epidermal growth factor receptor signal transactivation. Cancer Res. 2002, 62, 6329-6336.

220. Baudhuin, L.M.; Jiang, Y.; Zaslavsky, A.; Ishii, I.; Chun, J.; Xu, Y. S1P3-mediated Akt activation and cross-talk with platelet-derived growth factor receptor (PDGFR). FASEB J. 2004, 18, 341-343. [CrossRef]

221. Hellberg, C.; Schmees, C.; Karlsson, S.; Ahgren, A.; Heldin, C.H. Activation of protein kinase C alpha is necessary for sorting the PDGF beta-receptor to Rab4a-dependent recycling. Mol. Biol. Cell 2009, 20, 2856-2863. [CrossRef] [PubMed]

222. Goppelt-Struebe, M.; Fickel, S.; Reiser, C.O. The platelet-derived-growth-factor receptor, not the epidermal-growth-factor receptor, is used by lysophosphatidic acid to activate p42/44 mitogen-activated protein kinase and to induce prostaglandin G/H synthase-2 in mesangial cells. Biochem. J. 2000, 345, 217-224. [CrossRef] [PubMed]

223. Herrlich, A.; Daub, H.; Knebel, A.; Herrlich, P.; Ullrich, A.; Schultz, G.; Gudermann, T. Ligand-independent activation of platelet-derived growth factor receptor is a necessary intermediate in lysophosphatidic, acid-stimulated mitogenic activity in L cells. Proc. Natl. Acad. Sci. USA 1998, 95, 8985-8990. [CrossRef] [PubMed]

224. Wang, L.; Cummings, R.; Zhao, Y.; Kazlauskas, A.; Sham, J.K.; Morris, A.; Georas, S.; Brindley, D.N.; Natarajan, V. Involvement of phospholipase D2 in lysophosphatidate-induced transactivation of platelet-derived growth factor receptor-beta in human bronchial epithelial cells. J. Biol. Chem. 2003, 278, 39931-39940. [CrossRef] [PubMed] 
225. Nan, L.; Wei, J.; Jacko, A.M.; Culley, M.K.; Zhao, J.; Natarajan, V.; Ma, H.; Zhao, Y. Cross-talk between lysophosphatidic acid receptor 1 and tropomyosin receptor kinase A promotes lung epithelial cell migration. Biochim. Biophys. Acta 2016, 1863, 229-235. [CrossRef] [PubMed]

226. Abdulkhalek, S.; Guo, M.; Amith, S.R.; Jayanth, P.; Szewczuk, M.R. G-protein coupled receptor agonists mediate Neu1 sialidase and matrix metalloproteinase- 9 cross-talk to induce transactivation of TOLL-like receptors and cellular signaling. Cell. Signal. 2012, 24, 2035-2042. [CrossRef] [PubMed]

227. Zhao, Y.; He, D.; Stern, R.; Usatyuk, P.V.; Spannhake, E.W.; Salgia, R.; Natarajan, V. Lysophosphatidic acid modulates c-Met redistribution and hepatocyte growth factor/c-Met signaling in human bronchial epithelial cells through PKC delta and E-cadherin. Cell. Signal. 2007, 19, 2329-2338. [CrossRef] [PubMed]

228. Madhusoodanan, K.S.; Guo, D.; McGarrigle, D.K.; Maack, T.; Huang, X.Y. Csk mediates G-protein-coupled lysophosphatidic acid receptor-induced inhibition of membrane-bound guanylyl cyclase activity. Biochemistry 2006, 45, 3396-3403. [CrossRef] [PubMed]

229. Muller, D.; Cortes-Dericks, L.; Budnik, L.T.; Brunswig-Spickenheier, B.; Pancratius, M.; Speth, R.C.; Mukhopadhyay, A.K.; Middendorff, R. Homologous and lysophosphatidic acid-induced desensitization of the atrial natriuretic peptide receptor, guanylyl cyclase-A, in MA-10 leydig cells. Endocrinology 2006, 147, 2974-2985. [CrossRef] [PubMed]

230. Abbey, S.E.; Potter, L.R. Lysophosphatidic acid inhibits C-type natriuretic peptide activation of guanylyl cyclase-B. Endocrinology 2003, 144, 240-246. [CrossRef] [PubMed]

231. Zhao, Y.; He, D.; Saatian, B.; Watkins, T.; Spannhake, E.W.; Pyne, N.J.; Natarajan, V. Regulation of lysophosphatidic acid-induced epidermal growth factor receptor transactivation and interleukin-8 secretion in human bronchial epithelial cells by protein kinase Cdelta, Lyn kinase, and matrix metalloproteinases. J. Biol. Chem. 2006, 281, 19501-19511. [CrossRef] [PubMed]

232. Dikic, I.; Tokiwa, G.; Lev, S.; Courtneidge, S.A.; Schlessinger, J. A role for Pyk2 and Src in linking G-protein-coupled receptors with MAP kinase activation. Nature 1996, 383, 547-550. [CrossRef] [PubMed]

233. Jia, W.; Tran, S.K.; Ruddick, C.A.; Murph, M.M. The Src homology 3 binding domain is required for lysophosphatidic acid 3 receptor-mediated cellular viability in melanoma cells. Cancer Lett. 2015, 356, 589-596. [CrossRef] [PubMed]

234. Ha, J.H.; Ward, J.D.; Radhakrishnan, R.; Jayaraman, M.; Song, Y.S.; Dhanasekaran, D.N. Lysophosphatidic acid stimulates epithelial to mesenchymal transition marker Slug/Snail2 in ovarian cancer cells via Galphai2, Src, and HIF1alpha signaling nexus. Oncotarget 2016, 7, 37664-37679. [CrossRef] [PubMed]

235. Seo, J.H.; Jeong, K.J.; Oh, W.J.; Sul, H.J.; Sohn, J.S.; Kim, Y.K.; Cho, D.Y.; Kang, J.K.; Park, C.G.; Lee, H.Y. Lysophosphatidic acid induces STAT3 phosphorylation and ovarian cancer cell motility: Their inhibition by curcumin. Cancer Lett. 2010, 288, 50-56. [CrossRef] [PubMed]

236. Hopkins, M.M.; Zhang, Z.; Liu, Z.; Meier, K.E. Eicosopentaneoic Acid and Other Free Fatty Acid Receptor Agonists Inhibit Lysophosphatidic Acid- and Epidermal Growth Factor-Induced Proliferation of Human Breast Cancer Cells. J. Clin. Med. 2016, 5, 16. [CrossRef] [PubMed]

237. Ren, Y.; Pan, C.; Wu, Q.; Pang, Y.; Tang, C.; Qi, Y. [Involvement of endothelin in the proliferative effect of lysophosphatidic acid on vascular smooth muscle cells in rats]. Beijing Da Xue Xue Bao Yi Xue Ban 2003, 35, 508-511. [PubMed]

238. Shumay, E.; Tao, J.; Wang, H.Y.; Malbon, C.C. Lysophosphatidic acid regulates trafficking of beta2-adrenergic receptors: The Galpha13/p115RhoGEF/JNK pathway stimulates receptor internalization. J. Biol. Chem. 2007, 282, 21529-21541. [CrossRef] [PubMed]

239. Garcia-Sainz, J.A.; Vazquez-Cuevas, F.G.; Romero-Avila, M.T. Phosphorylation and desensitization of alpha1d-adrenergic receptors. Biochem. J. 2001, 353, 603-610. [CrossRef] [PubMed]

240. Apaydin, S.; Oktem, H.A. Modulatory role of lysophosphatidic acid on opioid receptor binding. Neurobiology (Bp.) 1998, 6, 421-427. [PubMed]

241. Callihan, P.; Ali, M.W.; Salazar, H.; Quach, N.; Wu, X.; Stice, S.L.; Hooks, S.B. Convergent regulation of neuronal differentiation and Erk and Akt kinases in human neural progenitor cells by lysophosphatidic acid, sphingosine 1-phosphate, and LIF: Specific roles for the LPA1 receptor. ASN Neuro 2014, 6, e1759091414558416. [CrossRef] [PubMed]

242. Shida, D.; Fang, X.; Kordula, T.; Takabe, K.; Lepine, S.; Alvarez, S.E.; Milstien, S.; Spiegel, S. Cross-talk between LPA1 and epidermal growth factor receptors mediates up-regulation of sphingosine kinase 1 to promote gastric cancer cell motility and invasion. Cancer Res. 2008, 68, 6569-6577. [CrossRef] [PubMed] 
243. Nakanaga, K.; Hama, K.; Kano, K.; Sato, T.; Yukiura, H.; Inoue, A.; Saigusa, D.; Tokuyama, H.; Tomioka, Y.; Nishina, H.; et al. Overexpression of autotaxin, a lysophosphatidic acid-producing enzyme, enhances cardia bifida induced by hypo-sphingosine-1-phosphate signaling in zebrafish embryo. J. Biochem. 2014, 155, 235-241. [CrossRef] [PubMed]

244. Watterson, K.R.; Lanning, D.A.; Diegelmann, R.F.; Spiegel, S. Regulation of fibroblast functions by lysophospholipid mediators: Potential roles in wound healing. Wound Repair Regen. 2007, 15, 607-616. [CrossRef] [PubMed]

245. Wu, J.; Mukherjee, A.; Lebman, D.A.; Fang, X. Lysophosphatidic acid-induced p21Waf1 expression mediates the cytostatic response of breast and ovarian cancer cells to TGFbeta. Mol. Cancer Res. 2011, 9, 1562-1570. [CrossRef] [PubMed]

246. Rodriguez Perez, C.E.; Nie, W.; Sinnett-Smith, J.; Rozengurt, E.; Yoo, J. TNF-alpha potentiates lysophosphatidic acid-induced COX-2 expression via PKD in human colonic myofibroblasts. Am. J. Physiol. Gastrointest. Liver Physiol. 2011, 300, 637-646. [CrossRef] [PubMed]

247. Hisano, Y.; Kono, M.; Cartier, A.; Engelbrecht, E.; Kano, K.; Kawakami, K.; Xiong, Y.; Piao, W.; Galvani, S.; Yanagida, K.; et al. Lysolipid receptor cross-talk regulates lymphatic endothelial junctions in lymph nodes. J. Exp. Med. 2019, 216, 1582-1598. [CrossRef] [PubMed]

248. Sakai, T.; Peyruchaud, O.; Fassler, R.; Mosher, D.F. Restoration of beta1A integrins is required for lysophosphatidic acid-induced migration of beta1-null mouse fibroblastic cells. J. Biol. Chem. 1998, 273, 19378-19382. [CrossRef]

249. Xu, M.Y.; Porte, J.; Knox, A.J.; Weinreb, P.H.; Maher, T.M.; Violette, S.M.; McAnulty, R.J.; Sheppard, D.; Jenkins, G. Lysophosphatidic acid induces alphavbeta6 integrin-mediated TGF-beta activation via the LPA2 receptor and the small G protein G alpha(q). Am. J. Pathol. 2009, 174, 1264-1279. [CrossRef]

250. Xu, M.; Yin, H.; Cai, Y.; Huang, W.; Ji, Q.; Liu, F.; Shi, S.; Deng, X. Lysophosphatidic acid induces integrin beta6 expression in human oral squamous cell carcinomas cells via LPAR1 coupling to Galphai and downstream SMAD3 and ETS-1 activation. Cell. Signal. 2019, 60, 81-90. [CrossRef]

251. Valenick, L.V.; Schwarzbauer, J.E. Ligand density and integrin repertoire regulate cellular response to LPA. Matrix Biol. 2006, 25, 223-231. [CrossRef] [PubMed]

252. Waters, C.M.; Saatian, B.; Moughal, N.A.; Zhao, Y.; Tigyi, G.; Natarajan, V.; Pyne, S.; Pyne, N.J. Integrin signalling regulates the nuclear localization and function of the lysophosphatidic acid receptor-1 (LPA1) in mammalian cells. Biochem. J. 2006, 398, 55-62. [CrossRef] [PubMed]

253. Walsh, C.T.; Stupack, D.; Brown, J.H. G protein-coupled receptors go extracellular: RhoA integrates the integrins. Mol. Interv. 2008, 8, 165-173. [CrossRef] [PubMed]

254. Chen, M.; O'Connor, K.L. Integrin alpha6beta4 promotes expression of autotaxin/ENPP2 autocrine motility factor in breast carcinoma cells. Oncogene 2005, 24, 5125-5130. [CrossRef] [PubMed]

255. Perrakis, A.; Moolenaar, W.H. Autotaxin: Structure-function and signaling. J. Lipid Res. 2014, 55, 1010-1018. [CrossRef] [PubMed]

256. Zhao, Y.; Hasse, S.; Zhao, C.; Bourgoin, S.G. Targeting the autotaxin-Lysophosphatidic acid receptor axis in cardiovascular diseases. Biochem. Pharmacol. 2019, 164, 74-81. [CrossRef] [PubMed]

257. Hu, J.; Oda, S.K.; Shotts, K.; Donovan, E.E.; Strauch, P.; Pujanauski, L.M.; Victorino, F.; Al-Shami, A.; Fujiwara, Y.; Tigyi, G.; et al. Lysophosphatidic acid receptor 5 inhibits B cell antigen receptor signaling and antibody response. J. Immunol. 2014, 193, 85-95. [CrossRef]

258. Rubenfeld, J.; Guo, J.; Sookrung, N.; Chen, R.; Chaicumpa, W.; Casolaro, V.; Zhao, Y.; Natarajan, V.; Georas, S. Lysophosphatidic acid enhances interleukin-13 gene expression and promoter activity in T cells. Am. J. Physiol. Lung Cell Mol. Physiol. 2006, 290, 66-74. [CrossRef]

259. Snider, A.J.; Zhang, Z.; Xie, Y.; Meier, K.E. Epidermal growth factor increases lysophosphatidic acid production in human ovarian cancer cells: Roles for phospholipase D2 and receptor transactivation. Am. J. Physiol. Cell Physiol. 2010, 298, 163-170. [CrossRef]

260. Moughal, N.A.; Waters, C.; Sambi, B.; Pyne, S.; Pyne, N.J. Nerve growth factor signaling involves interaction between the Trk A receptor and lysophosphatidate receptor 1 systems: Nuclear translocation of the lysophosphatidate receptor 1 and Trk A receptors in pheochromocytoma 12 cells. Cell. Signal. 2004, 16, 127-136. [CrossRef]

261. Lidgerwood, G.E.; Pitson, S.M.; Bonder, C.; Pebay, A. Roles of lysophosphatidic acid and sphingosine-1-phosphate in stem cell biology. Prog. Lipid Res. 2018, 72, 42-54. [CrossRef] [PubMed] 
262. Wang, X.; Huai, G.; Wang, H.; Liu, Y.; Qi, P.; Shi, W.; Peng, J.; Yang, H.; Deng, S.; Wang, Y. Mutual regulation of the Hippo/Wnt/LPA/TGFbeta signaling pathways and their roles in glaucoma (Review). Int. J. Mol. Med. 2018, 41, 1201-1212. [PubMed]

263. Yasuda, D.; Kobayashi, D.; Akahoshi, N.; Ohto-Nakanishi, T.; Yoshioka, K.; Takuwa, Y.; Mizuno, S.; Takahashi, S.; Ishii, S. Lysophosphatidic acid-induced YAP/TAZ activation promotes developmental angiogenesis by repressing Notch ligand Dll4. J. Clin. Investig. 2019, 129, 4332-4349. [CrossRef] [PubMed]

264. Ren, Z.; Zhang, C.; Ma, L.; Zhang, X.; Shi, S.; Tang, D.; Xu, J.; Hu, Y.; Wang, B.; Zhang, F.; et al. Lysophosphatidic acid induces the migration and invasion of SGC-7901 gastric cancer cells through the LPA2 and Notch signaling pathways. Int. J. Mol. Med. 2019, 44, 67-78. [CrossRef] [PubMed]

265. Yu, F.X.; Zhao, B.; Panupinthu, N.; Jewell, J.L.; Lian, I.; Wang, L.H.; Zhao, J.; Yuan, H.; Tumaneng, K.; Li, H.; et al. Regulation of the Hippo-YAP pathway by G-protein-coupled receptor signaling. Cell 2012, 150, 780-791. [CrossRef]

266. Zaslavsky, A.; Singh, L.S.; Tan, H.; Ding, H.; Liang, Z.; Xu, Y. Homo- and hetero-dimerization of LPA/S1P receptors, OGR1 and GPR4. Biochim. Biophys. Acta 2006, 1761, 1200-1212. [CrossRef] [PubMed]

267. Liu, J.P.; Komachi, M.; Tomura, H.; Mogi, C.; Damirin, A.; Tobo, M.; Takano, M.; Nochi, H.; Tamoto, K.; Sato, K.; et al. Ovarian cancer $\mathrm{G}$ protein-coupled receptor 1-dependent and -independent vascular actions to acidic pH in human aortic smooth muscle cells. Am. J. Physiol. Heart Circ. Physiol. 2010, 299, 731-742. [CrossRef]

268. Colin-Santana, C.C.; Avendano-Vazquez, S.E.; Alcantara-Hernandez, R.; Garcia-Sainz, J.A. EGF and angiotensin II modulate lysophosphatidic acid LPA(1) receptor function and phosphorylation state. Biochim. Biophys. Acta 2011, 1810, 1170-1177. [CrossRef]

269. Rodland, K.D.; Bollinger, N.; Ippolito, D.; Opresko, L.K.; Coffey, R.J.; Zangar, R.; Wiley, H.S. Multiple mechanisms are responsible for transactivation of the epidermal growth factor receptor in mammary epithelial cells. J. Biol. Chem. 2008, 283, 31477-31487. [CrossRef]

270. Lu, J.; Xiao Yj, Y.J.; Baudhuin, L.M.; Hong, G.; Xu, Y. Role of ether-linked lysophosphatidic acids in ovarian cancer cells. J. Lipid Res. 2002, 43, 463-476.

271. Chen, S.U.; Chou, C.H.; Chao, K.H.; Lee, H.; Lin, C.W.; Lu, H.F.; Yang, Y.S. Lysophosphatidic acid up-regulates expression of growth-regulated oncogene-alpha, interleukin-8, and monocyte chemoattractant protein-1 in human first-trimester trophoblasts: Possible roles in angiogenesis and immune regulation. Endocrinology 2010, 151, 369-379. [CrossRef] [PubMed]

272. Sivashanmugam, P.; Tang, L.; Daaka, Y. Interleukin 6 mediates the lysophosphatidic acid-regulated cross-talk between stromal and epithelial prostate cancer cells. J. Biol. Chem. 2004, 279, 21154-21159. [CrossRef]

273. Sun, B.; Nishihira, J.; Suzuki, M.; Fukushima, N.; Ishibashi, T.; Kondo, M.; Sato, Y.; Todo, S. Induction of macrophage migration inhibitory factor by lysophosphatidic acid: Relevance to tumor growth and angiogenesis. Int. J. Mol. Med. 2003, 12, 633-641. [CrossRef] [PubMed]

274. Mihara, M.; Hashizume, M.; Yoshida, H.; Suzuki, M.; Shiina, M. IL-6/IL-6 receptor system and its role in physiological and pathological conditions. Clin. Sci. (Lond.) 2012, 122, 143-159. [CrossRef] [PubMed]

275. Seo, E.J.; Kwon, Y.W.; Jang, I.H.; Kim, D.K.; Lee, S.I.; Choi, E.J.; Kim, K.H.; Suh, D.S.; Lee, J.H.; Choi, K.U.; et al. Autotaxin Regulates Maintenance of Ovarian Cancer Stem Cells through Lysophosphatidic Acid-Mediated Autocrine Mechanism. Stem Cells 2016, 34, 551-564. [CrossRef] [PubMed]

276. Fan, Q.; Cai, Q.; Xu, Y. LPA Regulates SOX9 in Ovarian Cancer Cells; Gavin Publishers: Lisle, IL, USA, 2017.

277. Yart, A.; Chap, H.; Raynal, P. Phosphoinositide 3-kinases in lysophosphatidic acid signaling: Regulation and cross-talk with the Ras/mitogen-activated protein kinase pathway. Biochim. Biophys. Acta 2002, 1582, 107-111. [CrossRef]

278. Daub, H.; Wallasch, C.; Lankenau, A.; Herrlich, A.; Ullrich, A. Signal characteristics of G protein-transactivated EGF receptor. EMBO J. 1997, 16, 7032-7044. [CrossRef] [PubMed]

279. Castelino, F.V.; Varga, J. Emerging cellular and molecular targets in fibrosis: Implications for scleroderma pathogenesis and targeted therapy. Curr. Opin. Rheumatol. 2014, 26, 607-614. [CrossRef]

280. Li, L.; Tam, L.; Liu, L.; Jin, T.; Ng, D.S. Wnt-signaling mediates the anti-adipogenic action of lysophosphatidic acid through cross talking with the Rho/Rho associated kinase (ROCK) pathway. Biochem. Cell Biol. 2011, 89, 515-521. [CrossRef]

281. Chen, Y.; Wang, Y.; Yu, H.; Wang, F.; Xu, W. The cross talk between protein kinase A- and RhoA-mediated signaling in cancer cells. Exp. Biol. Med. (Maywood) 2005, 230, 731-741. [CrossRef] 
282. Farooqui, A.A.; Ong, W.Y.; Farooqui, T. Lipid mediators in the nucleus: Their potential contribution to Alzheimer's disease. Biochim. Biophys. Acta 2010, 1801, 906-916. [CrossRef] [PubMed]

283. Bektas, M.; Payne, S.G.; Liu, H.; Goparaju, S.; Milstien, S.; Spiegel, S. A novel acylglycerol kinase that produces lysophosphatidic acid modulates cross talk with EGFR in prostate cancer cells. J. Cell Biol. 2005, 169, 801-811. [CrossRef] [PubMed]

284. Wong, J.L.; Obermajer, N.; Odunsi, K.; Edwards, R.P.; Kalinski, P. Synergistic COX2 Induction by IFNgamma and TNFalpha Self-Limits Type-1 Immunity in the Human Tumor Microenvironment. Cancer Immunol. Res. 2016, 4, 303-311. [CrossRef] [PubMed]

285. Reinartz, S.; Finkernagel, F.; Adhikary, T.; Rohnalter, V.; Schumann, T.; Schober, Y.; Nockher, W.A.; Nist, A.; Stiewe, T.; Jansen, J.M.; et al. A transcriptome-based global map of signaling pathways in the ovarian cancer microenvironment associated with clinical outcome. Genome Biol. 2016, 17, e108. [CrossRef] [PubMed]

286. Ray, R.; Rai, V. Lysophosphatidic acid converts monocytes into macrophages in both mice and humans. Blood 2017, 129, 1177-1183. [CrossRef] [PubMed]

287. Clair, T.; Aoki, J.; Koh, E.; Bandle, R.W.; Nam, S.W.; Ptaszynska, M.M.; Mills, G.B.; Schiffmann, E.; Liotta, L.A.; Stracke, M.L. Autotaxin hydrolyzes sphingosylphosphorylcholine to produce the regulator of migration, sphingosine-1-phosphate. Cancer Res. 2003, 63, 5446-5453. [PubMed]

288. Susanto, O.; Koh, Y.W.H.; Morrice, N.; Tumanov, S.; Thomason, P.A.; Nielson, M.; Tweedy, L.; Muinonen-Martin, A.J.; Kamphorst, J.J.; Mackay, G.M.; et al. LPP3 mediates self-generation of chemotactic LPA gradients by melanoma cells. J. Cell Sci. 2017, 130, 3455-3466. [CrossRef]

289. Brown, A.; Hossain, I.; Perez, L.J.; Nzirorera, C.; Tozer, K.; D’Souza, K.; Trivedi, P.C.; Aguiar, C.; Yip, A.M.; Shea, J.; et al. Lysophosphatidic acid receptor mRNA levels in heart and white adipose tissue are associated with obesity in mice and humans. PLoS ONE 2017, 12, e0189402. [CrossRef]

290. Takara, K.; Eino, D.; Ando, K.; Yasuda, D.; Naito, H.; Tsukada, Y.; Iba, T.; Wakabayashi, T.; Muramatsu, F.; Kidoya, H.; et al. Lysophosphatidic Acid Receptor 4 Activation Augments Drug Delivery in Tumors by Tightening Endothelial Cell-Cell Contact. Cell Rep. 2017, 20, 2072-2086. [CrossRef]

291. Sordelli, M.S.; Beltrame, J.S.; Zotta, E.; Gomez, N.; Dmytrenko, G.; Sales, M.E.; Blois, S.M.; Davio, C.; Martinez, S.P.; Franchi, A.M.; et al. Endogenous lysophosphatidic acid participates in vascularisation and decidualisation at the maternal-fetal interface in the rat. Reprod. Fertil. Dev. 2017, 29, 2112-2126. [CrossRef]

292. Cai, J.; Wei, J.; Li, S.; Suber, T.; Zhao, J. AM966, an Antagonist of Lysophosphatidic Acid Receptor 1, Increases Lung Microvascular Endothelial Permeability through Activation of Rho Signaling Pathway and Phosphorylation of VE-Cadherin. Mediat. Inflamm. 2017, 2017, e6893560. [CrossRef] [PubMed]

293. Ptaszynska, M.M.; Pendrak, M.L.; Stracke, M.L.; Roberts, D.D. Autotaxin signaling via lysophosphatidic acid receptors contributes to vascular endothelial growth factor-induced endothelial cell migration. Mol. Cancer Res. 2010, 8, 309-321. [CrossRef] [PubMed]

294. Mu, H.; Calderone, T.L.; Davies, M.A.; Prieto, V.G.; Wang, H.; Mills, G.B.; Bar-Eli, M.; Gershenwald, J.E. Lysophosphatidic acid induces lymphangiogenesis and IL-8 production in vitro in human lymphatic endothelial cells. Am. J. Pathol. 2012, 180, 2170-2181. [CrossRef] [PubMed]

295. Garraway, L.A.; Lander, E.S. Lessons from the cancer genome. Cell 2013, 153, 17-37. [CrossRef] [PubMed]

296. Vogelstein, B.; Papadopoulos, N.; Velculescu, V.E.; Zhou, S.; Diaz, L.A., Jr.; Kinzler, K.W. Cancer genome landscapes. Science 2013, 339, 1546-1558. [CrossRef] [PubMed]

297. Mateo, J.; Lord, C.J.; Serra, V.; Tutt, A.; Balmana, J.; Castroviejo-Bermejo, M.; Cruz, C.; Oaknin, A.; Kaye, S.B.; de Bono, J.S. A decade of clinical development of PARP inhibitors in perspective. Ann. Oncol. 2019. [CrossRef] [PubMed]

(C) 2019 by the author. Licensee MDPI, Basel, Switzerland. This article is an open access article distributed under the terms and conditions of the Creative Commons Attribution (CC BY) license (http://creativecommons.org/licenses/by/4.0/). 